\title{
Science Prospects and Benefits with Exascale Computing
}

\section{December 2007}

Prepared by Douglas B. Kothe Director of Science National Center for Computational Sciences

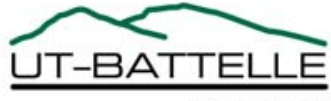




\title{
DOCUMENT AVAILABILITY
}

Reports produced after January 1, 1996, are generally available free via the U.S. Department of Energy (DOE) Information Bridge.

Web site http://www.osti.gov/bridge

Reports produced before January 1, 1996, may be purchased by members of the public from the following source.

\author{
National Technical Information Service \\ 5285 Port Royal Road \\ Springfield, VA 22161 \\ Telephone 703-605-6000 (1-800-553-6847) \\ TDD 703-487-4639 \\ Fax 703-605-6900 \\ E-mail info@ntis.fedworld.gov \\ Web site http://www.ntis.gov/support/ordernowabout.htm
}

Reports are available to DOE employees, DOE contractors, Energy Technology Data Exchange (ETDE) representatives, and International Nuclear Information System (INIS) representatives from the following source.

Office of Scientific and Technical Information

P.O. Box 62

Oak Ridge, TN 37831

Telephone 865-576-8401

Fax 865-576-5728

E-mail reports@osti.gov

Web site http://www.osti.gov/contact.html

This report was prepared as an account of work sponsored by an agency of the United States Government. Neither the United States government nor any agency thereof, nor any of their employees, makes any warranty, express or implied, or assumes any legal liability or responsibility for the accuracy, completeness, or usefulness of any information, apparatus, product, or process disclosed, or represents that its use would not infringe privately owned rights. Reference herein to any specific commercial product, process, or service by trade name, trademark, manufacturer, or otherwise, does not necessarily constitute or imply its endorsement, recommendation, or favoring by the United States Government or any agency thereof. The views and opinions of authors expressed herein do not necessarily state or reflect those of the United States Government or any agency thereof. 
ORNL/TM-2007/232

National Center for Computational Sciences

\title{
SCIENCE PROSPECTS AND BENEFITS WITH EXASCALE COMPUTING
}

\author{
Douglas B. Kothe
}

Director of Science

Date Published: December 2007

Prepared by

OAK RIDGE NATIONAL LABORATORY

Oak Ridge, Tennessee 37831-6283

managed by

UT-BATTELLE, LLC

for the

U.S. DEPARTMENT OF ENERGY

under contract DE-AC05-00OR22725 



\section{CONTENTS}

Page

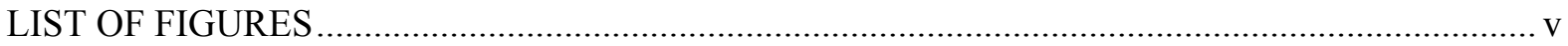

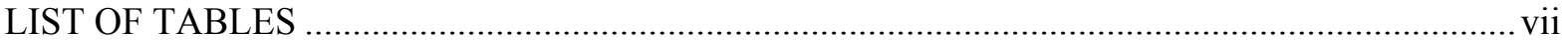

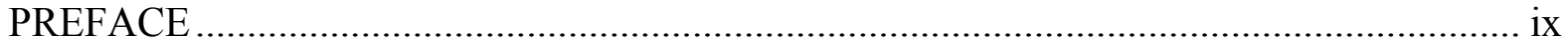

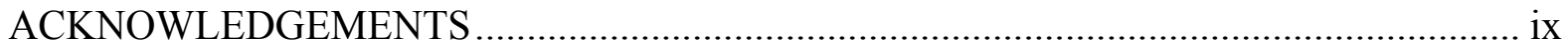

EXECUTIVE SUMMARY …..................................................................................... xi

1. LEADERSHIP COMPUTING: BUILDING FROM THE LAST REVOLUTION ............1

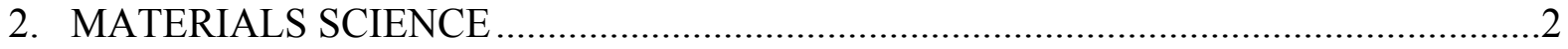

2.1 RECENT ACCOMPLISHMENTS WITH LEADERSHIP COMPUTING...............2

2.2 NEAR-TERM (PETASCALE) SCIENCE DRIVERS ..............................................

2.3 LONGER-TERM (SUSTAINED PETASCALE AND EXASCALE) SCIENCE

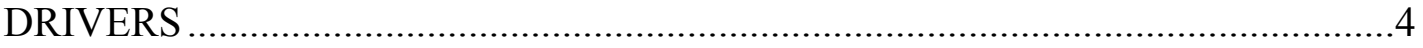

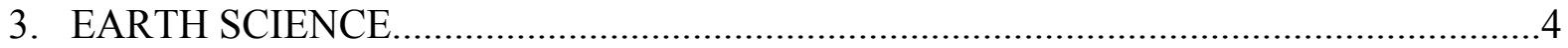

3.1 RECENT ACCOMPLISHMENTS WITH LEADERSHIP COMPUTING...............4

3.2 NEAR-TERM (PETASCALE) SCIENCE DRIVERS ..........................................

3.3 LONGER-TERM (SUSTAINED PETASCALE AND EXASCALE) SCIENCE

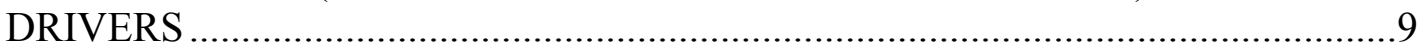

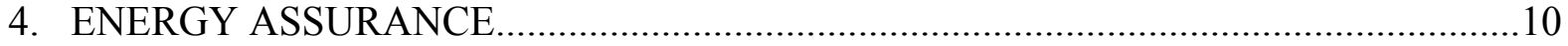

4.1 RECENT ACCOMPLISHMENTS WITH LEADERSHIP COMPUTING..............11

4.2 NEAR-TERM (PETASCALE) SCIENCE DRIVERS .............................................13

4.3 LONGER-TERM (SUSTAINED PETASCALE AND EXASCALE) SCIENCE

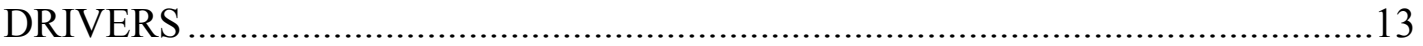

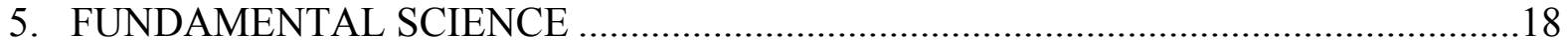

5.1 RECENT ACCOMPLISHMENTS WITH LEADERSHIP COMPUTING..............18

5.2 NEAR-TERM (PETASCALE) SCIENCE DRIVERS ...........................................19

5.3 LONGER-TERM (SUSTAINED PETASCALE AND EXASCALE) SCIENCE

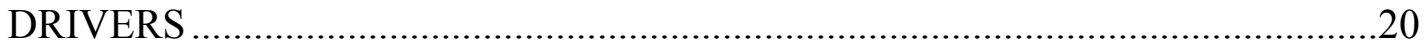

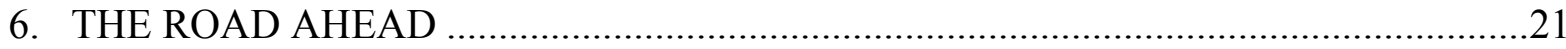

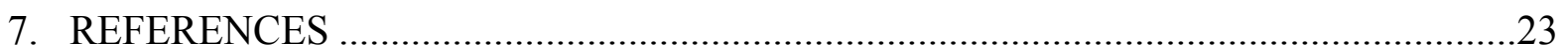





\section{LIST OF FIGURES}

Figure

Page

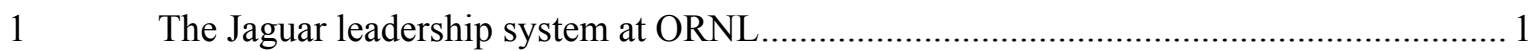

2 Crystal structure of the high-temperature cuprate superconductor $\mathrm{YBa}_{2} \mathrm{Cu}_{3} \mathrm{O}_{7} \ldots \ldots \ldots \ldots \ldots 2$

3 Instantaneous net ecosystem exchange viewed along the terminator

Getting the weather, climate variability, and climate change impacts right in global

climate models over the next decade will require the progressive evolution and coupling of multiple physical models

Future climate modeling will require much more powerful supercomputers .....................

U.S. energy flows in 2002

Direct numerical simulation of flame stabilization in a lifted hydrogen flame ................ 13

8 Recent simulation of a cellulase enzyme attacking a cellulose substrate performed at the LCF

9 Many protein and enzyme events of interest to biology and bioenergy research are in the millisecond-to-second timescales, which are orders of magnitude beyond those possible with today's simulations

10 Rendering of the matter entropy during the nonlinear phase of the standing accretion shock instability in a supernova core 



\section{LIST OF TABLES}

Table

Page

ES.1 The promise of exascale computing .........................................................................

1 Recent materials science accomplishments enabled by leadership computing at ORNL 3

2 Select materials science drivers for leadership computing at the petascale

(1 to 3 years) 4

Select materials science drivers for leadership computing at the exascale (10 years) ........5

4

Recent Earth science accomplishments enabled by leadership computing ........................6

Select Earth science drivers for leadership computing at the petascale (1 to 3 years)........ 8

Select Earth science drivers for leadership computing at the exascale (10 years) ............ 10

Recent energy assurance accomplishments enabled by leadership computing ................ 12

Select energy assurance drivers for leadership computing at the petascale

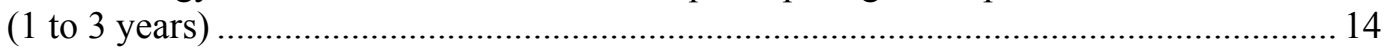

9 Select energy assurance drivers for leadership computing at the exascale (10 years)...... 15

10 Recent fundamental science accomplishments enabled by leadership computing ........... 18

11 Select fundamental science drivers for leadership computing at the petascale

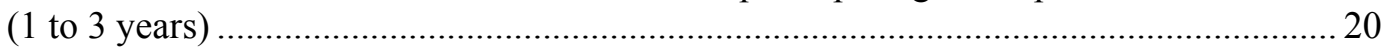

12 Select fundamental science drivers for leadership computing at the exascale

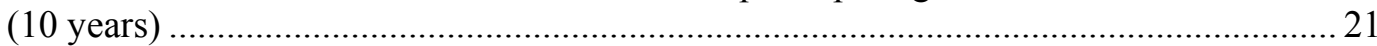

13 Science opportunities and impacts grow with increasingly capable leadership systems 



\section{PREFACE}

This discussion represents an initial assessment of the scientific advancements that will become plausible in the era of exascale computing and the profound challenges we face in getting there. We fully expect to refine and update it as we broaden our understanding with the aid of leading researchers and policy makers. Nevertheless, we believe it will contribute to the dialogue that must take place among all those who care about scientific and technological progress in the coming decades.

\section{ACKNOWLEDGEMENTS}

A document of this type would be impossible if we were not able to tap into the knowledge and wisdom of researchers from a broad range of institutions and the full gamut of scientific endeavors. At the risk of omitting one or more contributors, we would like to thank the following scientists, who freely shared their time and insights through personal discussion, interviews, and surveys: Pratul Agarwal, Valmor de Almeida, David Dean, John Drake, Tom Evans, Robert Harrison, Anthony Mezzacappa, Thomas Schulthess, Edward Uberbacher, Philip LoCascio, and Patrick Worley of Oak Ridge National Laboratory (ORNL); Jeff Candy of General Atomics; Jacqueline Chen of Sandia National Laboratories; Lei-Quan Lee of Stanford Linear Accelerator Center; Peter Lichtner of Los Alamos National Laboratory; Tommaso Roscilde of Max-Planck Gesellschaft; Benoit Roux of Argonne National Laboratory; and Wei-li Lee of Princeton Plasma Physics Laboratory. Without their insight, contributions, and vision, the case for science at the exascale as outlined in this document would not have had nearly as much impact or meaning.

We also acknowledge Ricky Kendall and the Scientific Computing Group within ORNL's National Center for Computational Sciences. In particular, Bronson Messer and James (Trey) White collected and edited key portions of the information contained in this document. And finally, thanks go to science writer Leo Williams of ORNL, who added a measure of conciseness and clarity of presentation to the final document. 



\section{EXECUTIVE SUMMARY}

Scientific computation has come into its own as a mature technology in all fields of science. Never before have we been able to accurately anticipate, analyze, and plan for complex events that have not yet occurred - from the operation of a reactor running at 100 million degrees centigrade to the changing climate a century down the road. Combined with the more traditional approaches of theory and experiment, scientific computation provides a profound tool for insight and solution as we look at complex systems containing billions of components. Nevertheless, it cannot yet do all we would like. Much of scientific computation's potential remains untapped - in areas such as materials science, Earth science, energy assurance, fundamental science, biology and medicine, engineering design, and national security - because the scientific challenges are far too enormous and complex for the computational resources at hand. Many of these challenges are of immediate global importance.

These challenges can be overcome by a revolution in computing that promises real advancement at a greatly accelerated pace. Planned petascale systems (capable of a petaflop, or $10^{15}$ floating point operations per second) in the next 3 years and exascale systems (capable of an exaflop, or $10^{18}$ floating point operations per second) in the next decade will provide an unprecedented opportunity to attack these global challenges through modeling and simulation. Exascale computers, with a processing capability similar to that of the human brain, will enable the unraveling of longstanding scientific mysteries and present new opportunities.

Table ES.1 summarizes these scientific opportunities, their key application areas, and the goals and associated benefits that would result from solutions afforded by exascale computing.

Table ES.1. The promise of exascale computing

\begin{tabular}{lll}
\hline Opportunity & \multicolumn{1}{c}{ Key application areas } & \multicolumn{1}{c}{ Goal and benefit } \\
\hline $\begin{array}{l}\text { Materials } \\
\text { science }\end{array}$ & $\begin{array}{l}\text { Nanoscale science; material lifecycles, } \\
\text { response, and failure; and manufacturing }\end{array}$ & $\begin{array}{l}\text { Design, characterize, and manufacture materials, } \\
\text { down to the nanoscale, tailored and optimized for } \\
\text { specific applications }\end{array}$ \\
Earth science & $\begin{array}{l}\text { Weather, carbon management, climate } \\
\text { change mitigation and adaptation, } \\
\text { environment }\end{array}$ & $\begin{array}{l}\text { Understand the complex biogeochemical cycles } \\
\text { that underpin global ecosystems and control the } \\
\text { sustainability of life on Earth }\end{array}$ \\
$\begin{array}{l}\text { Energy } \\
\text { assurance }\end{array}$ & $\begin{array}{l}\text { Fossil, fusion, combustion, nuclear fuel } \\
\text { cycle, chemical catalysis, renewables } \\
\text { (wind, solar, hydro), bioenergy, energy } \\
\text { efficiency, energy storage and } \\
\text { transmission, transportation, buildings }\end{array}$ & $\begin{array}{l}\text { Attain, without costly disruption, the energy } \\
\text { required by the United States in guaranteed, } \\
\text { economically viable, and environmentally benign } \\
\text { ways to satisfy residential, commercial, and } \\
\text { transportation requirements }\end{array}$ \\
$\begin{array}{l}\text { Fundamental } \\
\text { science }\end{array}$ & $\begin{array}{l}\text { High-energy physics, nuclear physics, } \\
\text { astrophysics, accelerator physics }\end{array}$ & $\begin{array}{l}\text { Decipher and comprehend the core laws } \\
\text { governing the universe and unravel its origins }\end{array}$ \\
$\begin{array}{l}\text { Biology and } \\
\text { medicine }\end{array}$ & $\begin{array}{l}\text { Proteomics, drug design, systems biology } \\
\text { Understand connections from individual proteins }\end{array}$ \\
$\begin{array}{l}\text { National } \\
\text { security }\end{array}$ & $\begin{array}{l}\text { Disaster management, homeland security, } \\
\text { defense systems, public policy }\end{array}$ & $\begin{array}{l}\text { Analyze, design, stress-test, and optimize critical } \\
\text { environments }\end{array}$ \\
& $\begin{array}{l}\text { systems such as communications, homeland } \\
\text { security, and defense systems; understand and } \\
\text { uncover human behavioral systems underlying } \\
\text { asymmetric operation environments }\end{array}$ \\
$\begin{array}{l}\text { Engineering } \\
\text { design }\end{array}$ & $\begin{array}{l}\text { Industrial and manufacturing processes } \\
\text { Design, deploy, and operate safe and economical } \\
\text { structures, machines, processes, and systems with } \\
\text { reduced concept-to-deployment time }\end{array}$ \\
\hline
\end{tabular}


The challenges presented in this document all require tightly coupled exascale computational platforms. Their solutions must draw from a variety of disciplines and incorporate a range of scales and physical processes. Mathematically they are governed by large sets of intricately linked equations. Distributed computing will not solve these problems, although it is appropriate for a host of other problems (large-scale data analysis, for example). Instead, the critical scientific challenges discussed here require hardware and software structures that can closely integrate many physical processes, each of which is a daunting computational challenge in itself. Such an integration cannot be made across a large, geographically or logically dispersed collection of processors. Real progress on these problems will wholly depend on the descendants of today's terascale (capable of a teraflop, or $10^{12}$ floating point operations per second) and tomorrow's petascale platforms.

If mathematics is the language of science, computation is its workhorse. Because highperformance computing addresses complexity, accelerates discovery, and enables progress in fields that could not advance without its aid, it has become science's "killer app"- the tool that drives a community to its use once that community views it as indispensable.

The advances outlined in this document are not inevitable. They will require a national commitment of time, talent, and money. Nevertheless, we cannot afford to fail. We must anticipate, mitigate, and adapt to a changing climate. We must provide a range of new energy sources - from fusion to biofuels to hydrogen - that are both cost-effective and plentiful. And we must expand our understanding of the universe, from the idiosyncrasies of subatomic systems to expanding galaxies. Each of these goals requires computing power orders of magnitude beyond what we have available, but each is well within our reach if we commit to achieving it.

Following a brief retrospective on leadership computing (Chap. 1), this document discusses the prospects for each of these scientific opportunities - in materials science (Chap. 2), Earth science (Chap. 3), energy assurance (Chap. 4), and fundamental science (Chap. 5) — drawing on data from and interviews with leading researchers $[1,2]$. This discussion focuses on the following areas:

- science accomplishments to date on leadership computing systems,

- near-term (1- to 3-year) petascale science drivers, and

- longer-term (5- to 10-year) exascale science drivers.

After looking at what will be feasible in the next 5 to 10 years and the major challenges remaining, this document concludes that important, high-impact global challenges have a high likelihood of being tackled and solved with the aid and guidance of exascale computing resources (Chap. 6). 


\section{LEADERSHIP COMPUTING: BUILDING FROM THE LAST REVOLUTION}

Researchers at the turn of the millennium realized they would need far more powerful computing tools to meet the challenges of an increasingly complex world [3-6]. In response to their demands, the Leadership Computing Facility (LCF) was established to provide resources 100 times more powerful than the most advanced systems available at the time. The LCF effort is exemplified by Oak Ridge National Laboratory's (ORNL's) Jaguar supercomputer (Fig. 1).

The 2004 LCF proposal summarized the research outlook of more than half a dozen science domains [7]. Nearly two dozen leading researchers and key collaborators united in calling for a national computing center, one that nurtures the kind of research that changes the world and the way we understand it. Some of their comments included the following:

- "The [LCF] system proposed here will allow the community to model the global climate, including a dynamic carbon cycle and improved cloud physics while increasing the atmospheric resolution to a $30 \mathrm{~km}$ grid and including eddy resolving ocean models."

- "Capability computing is required in fusion energy studies to enable researchers to describe the new physics regimes needed to model advanced experiments such as ITER [the multinational ITER reactor] - higher spatial resolutions, higher temperature plasma, longer simulation times and higher model dimensionality."

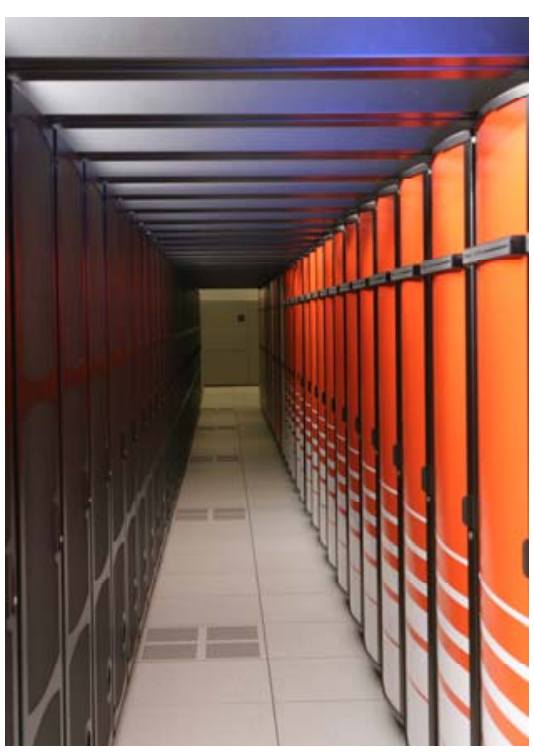

Fig. 1. The Jaguar leadership system at ORNL. to...achieve an understanding of the essential physics of high- $\mathrm{T}_{\mathrm{c}}$ [high-temperature] superconductors."

The LCF met these demands in two ways. First, it brought in state-of-the art supercomputers, systems that offered previously unseen power for open scientific research. Second, it took a revolutionary approach to the job of running a supercomputing center. The LCF has a staff of scientists dedicated to ensuring that each project takes the fullest advantage of these unique, nextgeneration systems, and the supercomputers themselves are reserved for projects so ambitious they cannot be accomplished anywhere else.

The promise of the LCF has been realized: Multicentury climate simulations (unheard of just a few years ago) are shedding new insight on climate change and its causes and impacts; unique threedimensional simulations of tokamak plasma are driving ITER design choices; and researchers have discovered that a purely electronic model successfully describes high-temperature superconductors (see Fig. 2). The LCF looks back and celebrates the scientific achievements made possible through terascale computing. It also looks forward to the next generation of systems that will usher in a new era of science exploration and application.

These and other science achievements and opportunities are described in the following chapters. 


\section{MATERIALS SCIENCE}

\subsection{RECENT ACCOMPLISHMENTS WITH LEADERSHIP COMPUTING}

Leadership computing has enabled a broad range of discoveries and remarkable advances in nanoscience and materials science (for example, see Fig. 2). From spintronics with applications to ultrahigh-density magnetic storage, thermoelectric converters to the theory of high-temperature superconductivity, supercomputers have accelerated the pace of advances in both basic science and application. Computational predictions [8] supported by experimental confirmation [9] brought us the MgO-based magnetic tunnel junctions used in today's highdensity hard drives, meaning computers, digital cameras, and MP3 players can now hold many gigabytes of data. Table 1 presents a brief list of similar accomplishments, with many more available in Yang and Chen 2007 [10]. Computational materials scientists clearly understand the impact and essential role of leadership computing in materials science and technology, as indicated by the following comments:

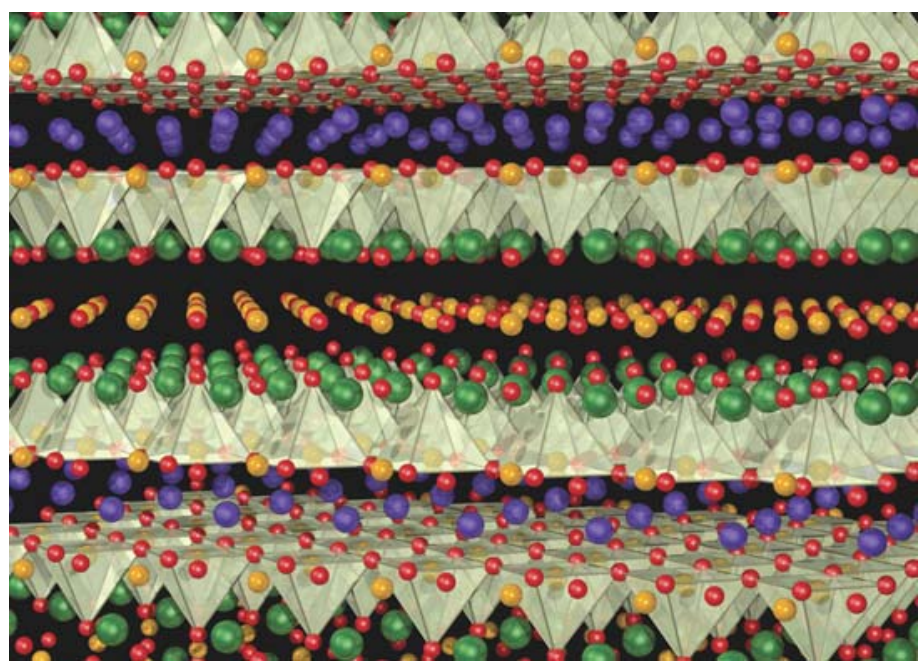

Fig. 2. Crystal structure of the high-temperature cuprate superconductor $\mathrm{YBa}_{2} \mathrm{Cu}_{3} \mathrm{O}_{7}$. The superconducting copper-oxide planes are modeled with a two-dimensional Hubbard model [6]

- "Quantum mechanical ab initio calculations are usually done with 200 to 300 atoms. We're doing calculations with a unit cell of more than 1,000 atoms. People would not be able to dream of doing these calculations without a large computing facility." (Jihui Yang, General Motors)

- "Theory and computation can be of tremendous value in helping to understand experimental results but also can provide new insight into physical and chemical processes that would otherwise be extremely difficult to obtain." (Bobby Sumpter, ORNL)

- "Without LCF and the INCITE [Innovative and Novel Computational Impact on Theory and Experiment] award, we simply cannot run our job. ... Due to the larger computer, we can do new science, not just higher-quality science." (Lin-Wang Wang, Lawrence Berkeley National Laboratory)

Leadership computing allows for deeper penetration - higher-quality and higher-productivity science - into any investigation. This holds for a broad range of challenges in materials science and technology, including these examples:

- Nanomaterials theory

- Emergent behavior/strongly correlated systems: spin fluctuations and pairing mechanism in cuprates (high-temperature superconductivity)

- Spin and charge transport in nanostructures

- Nanobiotechnology and statistical physics of nanoscale systems

- Nanomagnetism (particles, wires, multilayers) 
Table 1. Recent materials science accomplishments enabled by leadership computing at ORNL

\begin{tabular}{|c|c|c|c|}
\hline Accomplishment & Description & Impact & Leadership computing role \\
\hline $\begin{array}{l}\text { Turning vehicle } \\
\text { exhaust into } \\
\text { electricity }\end{array}$ & $\begin{array}{l}\text { Use of first-principles } \\
\text { calculations to study a } \\
\text { thermoelectric } \\
\text { material }[10]\end{array}$ & $\begin{array}{l}\text { Ability to convert a } \\
\text { portion of waste heat } \\
\text { generated by motor } \\
\text { vehicle engines into } \\
\text { usable electricity, making } \\
\text { vehicles more fuel- } \\
\text { efficient }\end{array}$ & $\begin{array}{l}\text { Simulation of various } \\
\text { properties of the material in a } \\
\text { supercell of more than } 1,000 \\
\text { atoms, rather than } 200 \text { to } 300 \\
\text { atoms as in previous } \\
\text { simulations }\end{array}$ \\
\hline $\begin{array}{l}\text { Resolving molecular } \\
\text { attachment }\end{array}$ & $\begin{array}{l}\text { Resolution of the } \\
\text { molecular structure of } \\
\text { successive layers of } \\
\text { methane as they attach } \\
\text { to magnesium oxide } \\
\text { [11] }\end{array}$ & $\begin{array}{l}\text { Improve our } \\
\text { understanding of } \\
\text { adsorption, a process with } \\
\text { enormous importance in } \\
\text { areas as diverse as fuel } \\
\text { storage, manufacturing, } \\
\text { and airport security }\end{array}$ & $\begin{array}{l}\text { Enabling of calculations } \\
\text { needed to understand this } \\
\text { system }\end{array}$ \\
\hline $\begin{array}{l}\text { Casting light on high- } \\
\text { temperature } \\
\text { superconductivity }\end{array}$ & $\begin{array}{l}\text { Solution of two- } \\
\text { dimensional Hubbard } \\
\text { model, showing a } \\
\text { purely electronic model } \\
\text { can describe super- } \\
\text { conductivity in high- } \\
\text { temperature } \\
\text { superconductors [12] }\end{array}$ & $\begin{array}{l}\text { Pave the way for advances } \\
\text { that may revolutionize } \\
\text { power generation as well } \\
\text { as electric transmission } \\
\text { and reduce the cost of } \\
\text { energy by adding } \\
\text { significantly to the } \\
\text { understanding of this } \\
\text { phenomenon }\end{array}$ & $\begin{array}{l}\text { Demonstration that Hubbard } \\
\text { Model can be reliably used to } \\
\text { study the physics of high- } \\
\text { temperature superconducting } \\
\text { cuprates }\end{array}$ \\
\hline $\begin{array}{l}\text { Boosting solar-cell } \\
\text { efficiency }\end{array}$ & $\begin{array}{l}\text { Use of Linear-Scaling } \\
\text { Density-Functional } \\
\text { Theory to study the } \\
\text { electronic structure of } \\
\text { zinc-tellurium } \\
\text { alloy [13] }\end{array}$ & $\begin{array}{l}\text { Use alloy in solar-energy } \\
\text { applications; boost the } \\
\text { efficiency of solar cells by } \\
\text { as much as } 50 \text { percent by } \\
\text { adding oxygen to the alloy }\end{array}$ & $\begin{array}{l}\text { Study of very large systems } \\
\text { (thousands of atoms) at the } \\
\text { quantum mechanical level, } \\
\text { feasible only on leadership- } \\
\text { class computers using an } \\
\text { aggregate of several thousand } \\
\text { CPUs }\end{array}$ \\
\hline
\end{tabular}

- Structural materials

- Micromechanics and nanomechanics of bulk and nanostructured materials

- Nuclear fuel performance/structural reactor materials

- Lightweight materials for transportation

- Designing and modeling materials processing: phase stability, kinetics, etc.

\subsection{NEAR-TERM (PETASCALE) SCIENCE DRIVERS}

Several key materials science drivers (motivators), objectives (tangible deliverables), and impacts have been identified as leading candidates for leadership computing accomplishments within the next 3 years (Table 2). These anticipated achievements are based on detailed interactions with leading members of the computational materials science community $[1,14]$. 
Table 2. Select materials science drivers for leadership computing at the petascale (1 to 3 years)

\begin{tabular}{|c|c|c|c|}
\hline $\begin{array}{l}\text { Application } \\
\quad \text { area }\end{array}$ & Science driver & Science objective & Impact \\
\hline \multirow[t]{7}{*}{$\begin{array}{l}\text { Nanoscale } \\
\text { science }\end{array}$} & \multirow{2}{*}{$\begin{array}{l}\text { Material-specific } \\
\text { understanding of } \\
\text { high-temperature } \\
\text { superconductivity } \\
\text { theory }\end{array}$} & \multirow{2}{*}{$\begin{array}{l}\text { Understand the quantitative } \\
\text { differences in the transition } \\
\text { temperatures of high-temperature } \\
\text { superconductors }\end{array}$} & $\begin{array}{l}\text { Macroscopic quantum effect } \\
\text { at elevated temperatures } \\
(>150 \mathrm{~K})\end{array}$ \\
\hline & & & $\begin{array}{l}\text { New materials for power } \\
\text { transmission and oxide } \\
\text { electronics }\end{array}$ \\
\hline & \multirow{4}{*}{$\begin{array}{l}\text { Thermodynamics of } \\
\text { nanostructures }\end{array}$} & \multirow{2}{*}{$\begin{array}{l}\text { Understand and improve colossally } \\
\text { magneto-resistive oxides and magnetic } \\
\text { semiconductors }\end{array}$} & Magnetic data storage \\
\hline & & & $\begin{array}{l}\text { Economically viable ethanol } \\
\text { production }\end{array}$ \\
\hline & & $\begin{array}{l}\text { Develop new switching mechanism in } \\
\text { magnetic nanoparticles for } \\
\text { ultrahigh-density storage }\end{array}$ & $\begin{array}{l}\text { Energy storage via structura } \\
\text { transitions in nanoparticles }\end{array}$ \\
\hline & & $\begin{array}{l}\text { Simulate and design molecular-scale } \\
\text { electronics devices }\end{array}$ & \\
\hline & $\begin{array}{l}\text { Evolution of an } \\
\text { understanding of } \\
\text { biological system } \\
\text { behavior }\end{array}$ & $\begin{array}{l}\text { Elucidate the physical-chemical } \\
\text { factors and mechanisms that control } \\
\text { damage to DNA }\end{array}$ & $\begin{array}{l}\text { Medicine, biomimetics, } \\
\text { sequence dependencies, and } \\
\text { inhibiting agents of } \\
\text { hazardous bioprocesses }\end{array}$ \\
\hline $\begin{array}{l}\text { Material } \\
\text { response }\end{array}$ & $\begin{array}{l}\text { Elucidation of the } \\
\text { causes leading to } \\
\text { eventual brittle or } \\
\text { ductile fragmentation } \\
\text { and failure of a solid }\end{array}$ & $\begin{array}{l}\text { Understand macro-cracking due to } \\
\text { coalescence of subscale cracks, local } \\
\text { deformation due to void coalescence, } \\
\text { and dynamic propagation of cracks or } \\
\text { shear bands }\end{array}$ & $\begin{array}{l}\text { Reduction of engineering } \\
\text { margins to within required } \\
\text { safe operating envelop }\end{array}$ \\
\hline
\end{tabular}

\subsection{LONGER-TERM (SUSTAINED PETASCALE AND EXASCALE) SCIENCE DRIVERS}

Materials science drivers, objectives, and impacts have been identified for leadership computing accomplishments considered possible on an exascale leadership computing platform deployed within the next decade (Table 3). These more speculative achievements are based on recent workshops [2] and personal communication with select members of the computational materials science community.

\section{EARTH SCIENCE}

\subsection{RECENT ACCOMPLISHMENTS WITH LEADERSHIP COMPUTING}

The LCF at ORNL provided more than a third of the U.S. contribution of computational resources to the February 2007 report of the Intergovernmental Panel on Climate Change (IPCC). High-performance computing guided the studies and conclusions that went into the report, leading to the 2007 Nobel Peace Prize for the IPCC in recognition of its work.

Earth science simulations at the LCF continue to play a key role in U.S. climate change research, bringing ORNL's leadership computing resources to studies of weather, carbon management, climate change mitigation and adaptation, and the environment, to name a few. For example, LCF systems provide much of the computing power for the Community Climate System Model (CCSM), a fully coupled, global climate model that provides state-of-the-art computer simulations of the Earth's past, present, and future climates (Fig. 3). In fact, the last few months of 2007 have seen many high-impact 
Earth science accomplishments, some of which are outlined in Table 4. Recent efforts include the evolution, development, and application of CCSM; high-resolution global ocean studies of thermohaline circulation and deep water formation; carbon-land model intercomparisons; and the impact of snow emissivity on regional climate models (using the WRF code).

Table 3. Select materials science drivers for leadership computing at the exascale (10 years)

\begin{tabular}{|c|c|c|c|}
\hline $\begin{array}{l}\text { Application } \\
\text { area }\end{array}$ & Science driver & Science objective & Impact \\
\hline \multirow[t]{5}{*}{$\begin{array}{l}\text { Nanoscale } \\
\text { science }\end{array}$} & $\begin{array}{l}\text { First-principles design of } \\
\text { increasingly complex } \\
\text { materials with specific, } \\
\text { targeted properties }\end{array}$ & $\begin{array}{l}\text { Understand and use isolated } \\
\text { nanostructures to design } \\
\text { materials made out of nano } \\
\text { building blocks }\end{array}$ & $\begin{array}{l}\text { Smart materials for } \\
\text { nanoelectronics, } \\
\text { photovoltaics, information } \\
\text { technology, and medicine }\end{array}$ \\
\hline & $\begin{array}{l}\text { Predictive description of } \\
\text { microscopic behavior of } \\
\text { water to understand systems } \\
\text { in aqueous environments }\end{array}$ & $\begin{array}{l}\text { Perform molecular dynamics } \\
\text { with forces found with Quantum } \\
\text { Monte Carlo computations }\end{array}$ & $\begin{array}{l}\text { Detailed understanding of the } \\
\text { structure of water- } \\
\text { fundamental understanding of } \\
\text { biological systems }\end{array}$ \\
\hline & \multirow[t]{2}{*}{$\begin{array}{l}\text { Understanding of synthesis } \\
\text { of alloy nanoparticles with } \\
\text { potential impact for design } \\
\text { of new catalysts }\end{array}$} & \multirow[t]{2}{*}{$\begin{array}{l}\text { Define the thermodynamics of } \\
\text { compositions of alloy } \\
\text { nanoparticles }\end{array}$} & $\begin{array}{l}\text { Magnetic data storage } \\
\text { Economically viable ethanol } \\
\text { production }\end{array}$ \\
\hline & & & $\begin{array}{l}\text { Energy storage via structural } \\
\text { transitions in nanoparticles }\end{array}$ \\
\hline & $\begin{array}{l}\text { Physics of strongly } \\
\text { correlated electron } \\
\text { materials }\end{array}$ & $\begin{array}{l}\text { Explain the fundamental } \\
\text { mechanism of high-temperature } \\
\text { superconductivity, including } \\
\text { materials specificity and } \\
\text { inhomogeneities }\end{array}$ & $\begin{array}{l}\text { New materials for practical } \\
\text { applications in oxide } \\
\text { electronics and } \\
\text { next-generation power } \\
\text { transmission }\end{array}$ \\
\hline
\end{tabular}

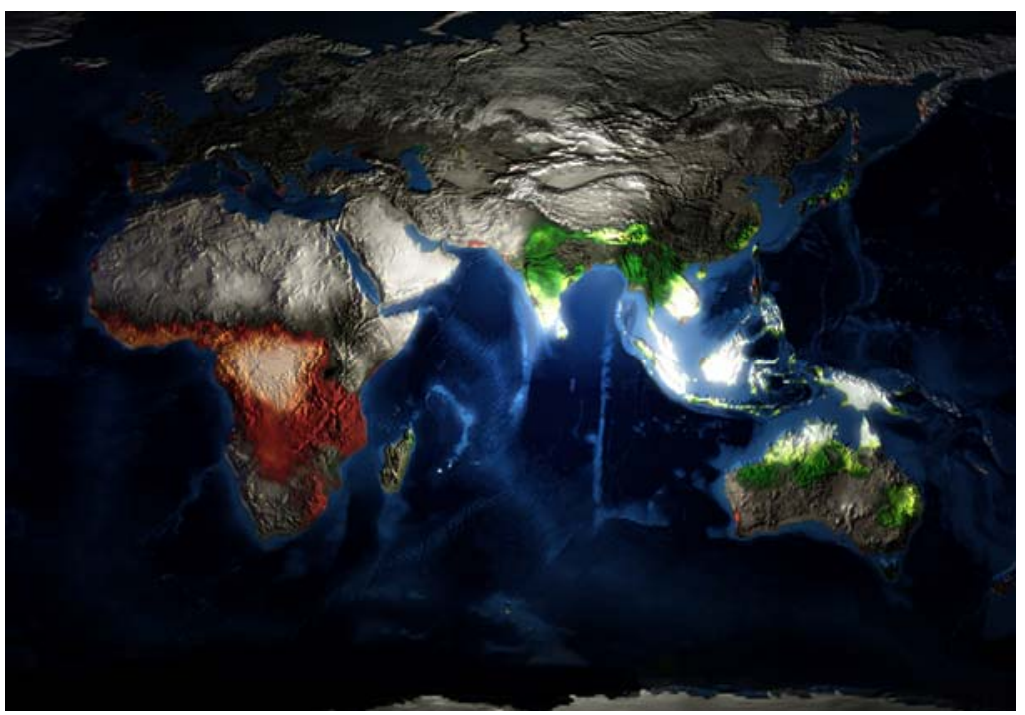

Fig. 3. Instantaneous net ecosystem exchange viewed along the terminator. The eastern half of this image is in sunlight and the terrestrial ecosystems are taking up carbon (shown in green to bright white). Meanwhile, the sun has not yet risen in the western half of the image, where the ecosystems are only respiring (shown in red). 
Table 4. Recent Earth science accomplishments enabled by leadership computing

\begin{tabular}{|c|c|c|c|}
\hline Accomplishment & Description & Impact & Leadership computing role \\
\hline $\begin{array}{l}\text { Eulerian and } \\
\text { Lagrangian } \\
\text { studies of } \\
\text { turbulent } \\
\text { transport in the } \\
\text { global ocean }\end{array}$ & $\begin{array}{l}\text { Simulation of the ocean at } \\
\text { high resolution }\left(0.1^{\circ}\right. \\
\text { longitude) for } 100 \text { years } \\
\text { and use of a suite of } \\
\text { passive tracers and } \\
\text { Lagrangian particles to } \\
\text { understand the role of } \\
\text { eddies and water transport } \\
\text { in the global ocean }\end{array}$ & $\begin{array}{l}\text { Create most realistic } \\
\text { global ocean circulation } \\
\text { simulation to date, helping } \\
\text { to correct deficiencies with } \\
\text { earlier simulations, which } \\
\text { could result in different } \\
\text { conclusions being drawn } \\
\text { in future climate scenarios } \\
\text { using eddying ocean } \\
\text { models }\end{array}$ & $\begin{array}{l}\text { Significantly improved fidelity } \\
\text { compared to earlier runs, so } \\
\text { will be used as the initial } \\
\text { condition for a fully coupled } \\
\text { climate simulation of } \\
\text { unprecedented scale } \\
\text { Ability to simulate in } 3 \text { months } \\
\text { on Jaguar what took } 10 \text { times as } \\
\text { long on previous-generation } \\
\text { machines }\end{array}$ \\
\hline $\begin{array}{l}\text { Carbon-land } \\
\text { model } \\
\text { intercomparison } \\
\text { project }\end{array}$ & $\begin{array}{l}\text { Development and critical } \\
\text { analysis of two terrestrial } \\
\text { biogeochemistry models }\end{array}$ & $\begin{array}{l}\text { Develop self-consistent } \\
\text { carbon cycle and land } \\
\text { models required for } \\
\text { predictive climate change } \\
\text { simulation capability }\end{array}$ & $\begin{array}{l}\text { Model development aided and } \\
\text { accelerated by required } \\
\text { intercomparison simulations }\end{array}$ \\
\hline CCSM & $\begin{array}{l}\text { Development, validation, } \\
\text { and application of next- } \\
\text { generation model for } \\
\text { Earth's past, present, and } \\
\text { future climate }\end{array}$ & $\begin{array}{l}\text { Develop and apply key } \\
\text { tool in the U.S. for } \\
\text { prediction and policy } \\
\text { decisions on climate } \\
\text { change mitigation and } \\
\text { adaptation scenarios }\end{array}$ & $\begin{array}{l}\text { Principal developmental and } \\
\text { application platform for IPCC } \\
\text { simulations }\end{array}$ \\
\hline $\begin{array}{l}\text { Reactive flows in } \\
\text { porous media }\end{array}$ & $\begin{array}{l}\text { Modeling of uranium } \\
\text { migration at Hanford } 300 \\
\text { area and exploration of } \\
\mathrm{CO}_{2} \text { sequestration in } \\
\text { reservoirs }\end{array}$ & $\begin{array}{l}\text { Understand role of } \\
\text { fingering in } \mathrm{CO}_{2} \\
\text { sequestration; develop } \\
\text { Hanford } 300 \text { conceptual } \\
\text { model }\end{array}$ & $\begin{array}{l}\text { Ability to model three- } \\
\text { dimensional systems at } \\
\text { sufficient spatial and temporal } \\
\text { resolution to capture relevant } \\
\text { physical processes }\end{array}$ \\
\hline
\end{tabular}

Looking ahead, four abrupt climate events will soon be tested against proxy records to search for the best route for melting water flux from retreating glaciers. A study of ocean eddies and their role in ocean transport will tell us if an eddying ocean model changes projections sufficiently to justify the much higher computational cost. And work on CCSM will move forward with continued development of the CCSM carbon, nitrogen, and biogeochemistry packages.

LCF assistance to the climate science community goes beyond providing the world's most powerful supercomputers for open scientific research. LCF scientific computing staff also provide key software and algorithm contributions to the climate teams; these include the insertion of new and more efficient linear solver preconditioners, the introduction of new data-analysis and visualization tools for carbon dioxide transport, and aid in identifying and fixing bugs in the global ocean model. As indicated by the following testimonies from key climate scientists using the LCF systems, these contributions are well appreciated:

- "[On Jaguar,] we got 100-year runs in 3 days. This was a significant upgrade of how we do science with this model. Forty years per day was out of our dreams." (Peter Gent, National Center for Atmospheric Research [NCAR])

- "The most impressive new result in 10 years." (Peter Gent, NCAR, referring to the El Niño/Southern Oscillation)

- "[The LCF has] been instrumental in being a bridge between our science and development teams and the computational resources." (Lawrence Buja, NCAR) 
- " “The Scientific Computing Liaisons ] really helped manage the code optimization." (John Drake, ORNL)

- "Applying leadership class computing to the climate problem allows us to include more realistic processes in the model; run at higher resolutions, which results in better transient solutions; carry out more ensemble runs, which reduce the uncertainty of the results; and run long historical simulations, allowing us to demonstrate that models reproduce the important features of the real climate system." (Warren Washington, NCAR, principal investigator, Climate Science Computational End Station Development and Grand Challenge Team)

- "We now have models that are highly scalable and are limited only by available hardware. DOE's [the Department of Energy's] proposal to make available the Leadership Computing Facility for this project provides an unprecedented match between capability computing resources and a stateof-the-art model." (Venkatramani Balaji, National Oceanic and Atmospheric Administration's Geophysical Fluid Dynamics Laboratory at Princeton University)

The concept and application of computational end stations as originally proposed in the LCF at ORNL has indeed come to fruition and is best typified by the successful Climate Science Computational End Station.

\subsection{NEAR-TERM (PETASCALE) SCIENCE DRIVERS}

As indicated in Fig. 4, in the next 3 to 5 years climate computational researchers will be focusing their efforts on improving understanding and predictability in three principal areas: weather (land, surface, atmosphere), climate variability (ocean, sea ice, biogeochemistry), and climate change impacts (carbon cycle, water cycle, economics). Several key Earth science drivers, objectives, and impacts have been identified as leading candidates for leadership computing accomplishments within the next 3 years (Table 5). These anticipated achievements are based on interactions with leading members of the computational Earth science community [1,14].

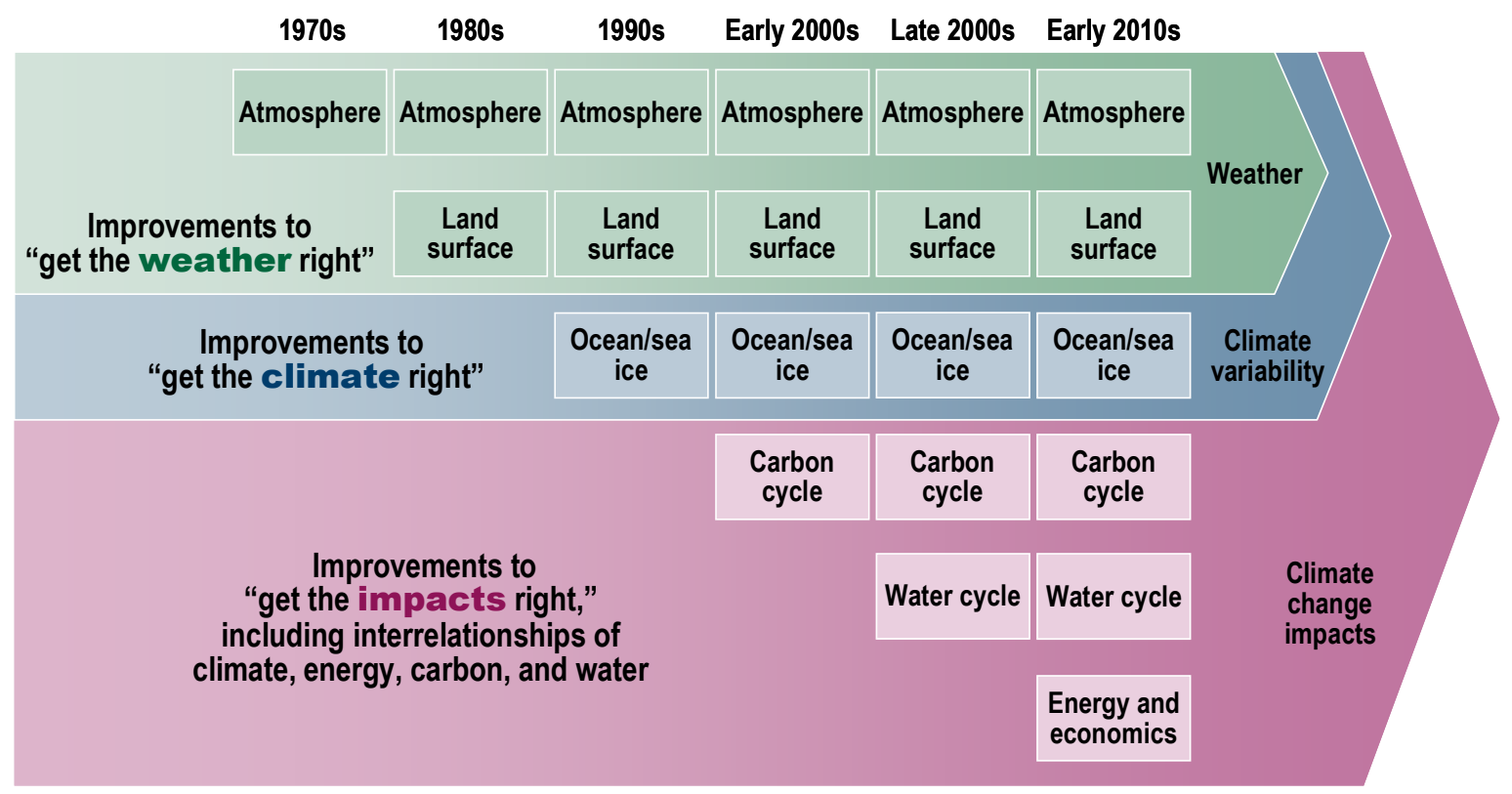

Fig. 4. Getting the weather, climate variability, and climate change impacts right in global climate models over the next decade will require the progressive evolution and coupling of multiple physical models. 
Table 5. Select Earth science drivers for leadership computing at the petascale (1 to 3 years)

\begin{tabular}{|c|c|c|c|}
\hline Application area & Science driver & Science objective & Impact \\
\hline \multirow[t]{3}{*}{ Climate } & $\begin{array}{l}\text { Simulation of dynamic } \\
\text { ecological and chemical } \\
\text { evolution of the climate } \\
\text { system }\end{array}$ & $\begin{array}{l}\text { Predict future climates based on } \\
\text { scenarios of anthropogenic } \\
\text { emissions and other changes } \\
\text { from options in energy policies }\end{array}$ & $\begin{array}{l}\text { Information for IPCC and } \\
\text { policy decisions on climate } \\
\text { change }\end{array}$ \\
\hline & $\begin{array}{l}\text { Development, delivery, } \\
\text { and support for CCSM }\end{array}$ & $\begin{array}{l}\text { Integrate and couple models for } \\
\text { ocean, sea ice, land, } \\
\text { atmosphere, cycles for } \\
\text { carbon/water, and } \\
\text { biogeochemistry }\end{array}$ & $\begin{array}{l}\text { Tool for climate change } \\
\text { prediction for input into } \\
\text { policy making }\end{array}$ \\
\hline & $\begin{array}{l}\text { Accurate representation } \\
\text { of ocean circulation }\end{array}$ & $\begin{array}{l}\text { Develop fully coupled eddy- } \\
\text { resolving ocean and sea ice } \\
\text { model to reduce the coupled } \\
\text { model biases where ice and } \\
\text { deep-water parameters are } \\
\text { governed by the accurate } \\
\text { representation of current } \\
\text { systems }\end{array}$ & $\begin{array}{l}\text { Reduction of current } \\
\text { uncertainties in coupled } \\
\text { ocean-sea ice system model }\end{array}$ \\
\hline Environment & $\begin{array}{l}\text { Performance of } \\
\text { multiscale, multiphase, } \\
\text { multicomponent } \\
\text { modeling of a three- } \\
\text { dimensional field } \mathrm{CO}_{2} \\
\text { injection scenario }\end{array}$ & $\begin{array}{l}\text { Include oil phase and four-phase } \\
\text { liquid-gas-aqueous-oil system to } \\
\text { describe dissipation of the } \\
\text { supercritical } \mathrm{CO}_{2} \text { phase and } \\
\text { escape of } \mathrm{CO}_{2} \text { to the surface }\end{array}$ & $\begin{array}{l}\text { Demonstration of viability } \\
\text { of and potential for a } \\
\text { predictive groundwater } \\
\text { transport model }\end{array}$ \\
\hline
\end{tabular}

Climate science drivers at the petascale reflect the ability to incorporate substantially more fidelity in the models. For example, CCSM at the petascale will be able to include the following:

- models for tropospheric chemistry (100 species),

- dynamic vegetation,

- terrestrial carbon and nitrogen cycles,

- ocean ecosystems,

- land ice sheets,

- stratospheric chemistry,

- full sulfur cycle,

- increase in ensemble size for climate change studies,

- coupled-ocean eddy-resolving simulations,

- cloud microphysics and interaction of aerosols with water,

- realistic land-use patterns, and

- tropical event simulation on climate timescales.

Biogeochemical processes, for example, will be modeled with an order-of-magnitude more variables than under the current approach [1]. Systematic errors and biases in climate models can also be reduced at the petascale, thereby increasing their utility as a predictive tool. Such reductions are likely to occur through improvements in existing physical parameterizations and a more accurate incorporation of phenomena. The internal dynamics of a system, for example, are more accurately represented at higher resolution. 


\subsection{LONGER-TERM (SUSTAINED PETASCALE AND EXASCALE) SCIENCE DRIVERS}

Earth science and climate change research will be focused on two principal activities in the decade ahead:

- mitigation: evaluating strategies and informing policy decisions for climate stabilization and

- adaptation: preparing for committed climate change with decadal forecasts and regional impacts.

Simulations of 100 to 1,000 years will be typical for mitigation activities, while shorter simulations of 10 to 100 years will be used for adaptation. Each set of simulations must be predictive and quantifiable to reliably inform policy makers. Requirements for leadership computing can be tied to these activities and goals, as shown in Table 5. For example, estimates call for compute factors $10^{10}$ to $10^{12}$ greater than those of today to meet goals for spatial resolution, model completeness, simulation times, and breadth and depth of ensembles and scenarios (Fig. 5).

Climate models are currently more reliable at short timescales and long, asymptotic scales. Model predictions in the 20- to 50-year range are currently less accurate, resulting in more uncertain forecasts. Table 6 gives some select Earth science drivers, objectives, and impacts for leadership computing accomplishments considered possible on an exascale platform deployed within the

\begin{tabular}{|l|l|c|}
\multicolumn{1}{|c|}{ Issue } & \multicolumn{1}{c|}{ Motivation } & Compute factor \\
\hline Spatial resolution & Provide regional details & $10^{3}-10^{5}$ \\
\hline Model completeness & Add "new" science & $10^{2}$ \\
\hline New parameterizations & Upgrade to "better" science & $10^{2}$ \\
\hline Run length & Long-term implications & $10^{2}$ \\
\hline Ensembles and scenarios & Range of model variability & $10^{1}$ \\
\hline & Total compute factor & $10^{10}-10^{12}$ \\
\hline
\end{tabular}

Fig. 5. Future climate modeling will require much more powerful supercomputers. next decade. These are based on recent workshops [2] and personal communication with select members of the computational Earth science community. This community has also done well in articulating what it believes to be attainable biogeochemical objectives over the next decade [2], including the following:

- integrated models and measurements of biogeochemical cycles,

- development of next-generation ecological models, and

- better theory for and quantification of uncertainty.

To reiterate, climate science opportunities at the exascale are abundant [15] and include advancement in the understanding of the following:

- decadal prediction on regional scales (accuracy in global models),

- climate extremes (heat waves, drought, floods, synoptic events, etc.),

- climate variability (low-frequency variability),

- water cycle (particularly in the tropics),

- human-induced impacts on the carbon cycle,

- sea-level rise (melting of the Greenland and Antarctic ice sheets), and

- abrupt climate change.

The rate limiters above are decadal prediction, abrupt climate change, and climate variability. 
Table 6. Select Earth science drivers for leadership computing at the exascale (10 years)

\begin{tabular}{|c|c|c|c|}
\hline Application area & Science driver & Science objective & Impact \\
\hline \multirow[t]{3}{*}{ Climate } & $\begin{array}{l}\text { Characterization and } \\
\text { bounding of the } \\
\text { coupled Earth } \\
\text { system }\end{array}$ & $\begin{array}{l}\text { Maintain tolerable time-integration } \\
\text { rates while increasing model } \\
\text { resolution and complexity; integrate } \\
\text { models and observations; model } \\
\text { biogeochemical cycles and coupled } \\
\text { physical and biogeochemical } \\
\text { systems at the process level }\end{array}$ & $\begin{array}{l}\text { Understanding and } \\
\text { prediction of stability and } \\
\text { sustainability of rain forests, } \\
\text { polar ice and ice sheets, } \\
\text { agricultural ecosystems, } \\
\text { precipitation, and methane } \\
\text { hydrates; understanding of } \\
\text { extreme weather; } \\
\text { quantification of mitigation } \\
\text { strategies }\end{array}$ \\
\hline & $\begin{array}{l}\text { Dynamical linking } \\
\text { of socioeconomic } \\
\text { and climate } \\
\text { responses }\end{array}$ & $\begin{array}{l}\text { Couple infrastructure, climate, } \\
\text { demographic, informational, and } \\
\text { energy economic models to predict } \\
\text { adaptation as communities react to } \\
\text { stresses on infrastructure systems } \\
\text { and propose potential policies }\end{array}$ & $\begin{array}{l}\text { Identification of future } \\
\text { energy-infrastructure needs }\end{array}$ \\
\hline & $\begin{array}{l}\text { Decadal climate } \\
\text { prediction }\end{array}$ & $\begin{array}{l}\text { Incorporate cloud-resolving ( } 1 \text { to } 5 \\
\text { kilometers) atmosphere, longer time } \\
\text { integration ( } 100 \text { to } 300 \text { years, } 1,000 \text { - } \\
\text { year spin-ups), and larger ensembles } \\
\text { (five to 20) }\end{array}$ & $\begin{array}{l}\text { Understanding of and } \\
\text { preparation for committed } \\
\text { climate change }\end{array}$ \\
\hline \multirow[t]{2}{*}{ Environment } & $\begin{array}{l}\text { Radioactive waste } \\
\text { management and } \\
\text { environmental } \\
\text { stewardship }\end{array}$ & $\begin{array}{l}\text { Simulate radionuclide plumes at } \\
\text { high resolution using stochastic } \\
\text { parameter and property fields with } \\
\text { meter and centimeter vertical } \\
\text { resolution }\end{array}$ & $\begin{array}{l}\text { Improvements to cleanup of } \\
\text { DOE Complex }\end{array}$ \\
\hline & $\begin{array}{l}\text { Carbon } \\
\text { sequestration in } \\
\text { geologic formations }\end{array}$ & $\begin{array}{l}\text { Model dissipation of supercritical } \\
\mathrm{CO}_{2} \text { injected in the subsurface } \\
\text { accounting for fingering phenomena } \\
\text { in kilometer-scale basin simulations }\end{array}$ & $\begin{array}{l}\text { Management of carbon } \\
\text { through active capture and } \\
\text { storage }\end{array}$ \\
\hline
\end{tabular}

\section{ENERGY ASSURANCE}

The production, use, and flow of energy in the United States result in a complex system, as shown in Fig. 6 for the year 2002. This system of energy flows is tightly balanced between supply and demand, and it does not have a "silver bullet," namely one particular energy type whose net change can significantly alter energy assurance on its own. Energy assurance-encompassing production, distribution, and consumption - is the ability to obtain, without costly disruption, the energy required by the United States in assured, economically-viable, and environmentally-benign ways to satisfy residential, commercial, and transportation needs. Energy assurance aims to avoid costly disruptions. While the causes of some such disruptions are beyond our control (weather, accidents, etc.), many others can be proactively controlled (reliability, redundancy, diversity, etc.). In those areas over which we do have control, small changes result in big impacts in energy supply, giving us many opportunities to further decrease the number of costly disruptions. 


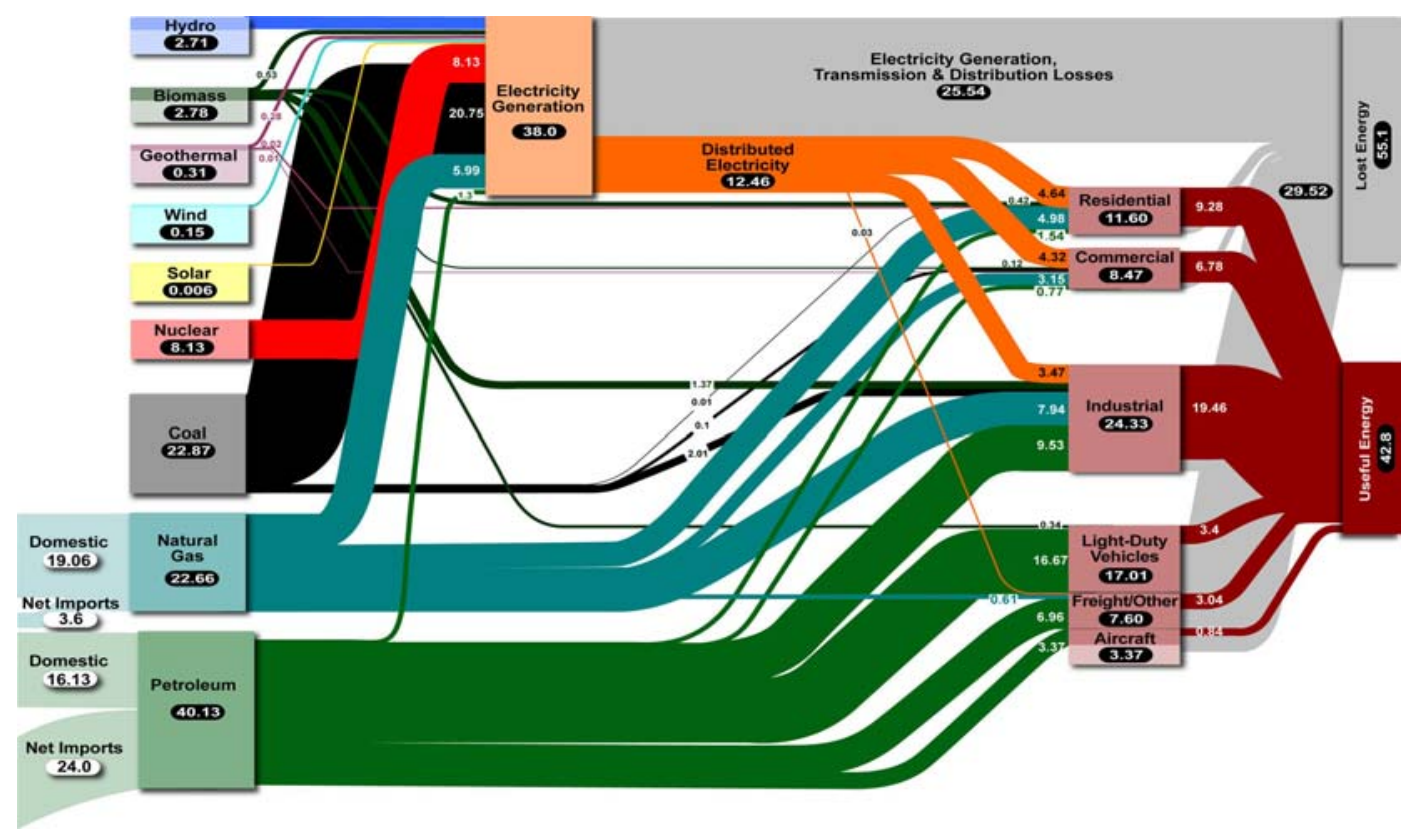

Fig. 6. U.S. energy flows in 2002. (Lawrence Livermore National Laboratory report, UCRLTR-129990-02, 2002) [16]

These changes must incorporate improvements to our energy legacy (oil, gas, coal, nuclear, conservation, efficiency, etc.), as well as development of new approaches (wind, solar, fusion, biomass, hydrogen, carbon sequestration, new distributions, etc.). It is here that leadership computing is needed; its value will accelerate to the exascale and beyond for systems-level modeling [17].

Energy assurance has been and will continue to be a major driver for leadership computing resources, as illustrated by the accomplishments achieved to date and those that will be achieved by future petascale and exascale systems. In analyzing the science drivers, challenges, and likely outcomes, we are confident that exascale leadership computing will deliver an immeasurable return on investment in the form of increased U.S. energy assurance.

\subsection{RECENT ACCOMPLISHMENTS WITH LEADERSHIP COMPUTING}

Energy production research - both fundamental and applied - has benefited greatly from the use of leadership computing. Recent simulations at the LCF have provided invaluable insight into core turbulence and radio-wave heating of ITER-like tokamak plasmas for magnetic fusion, turbulent combustion processes in diesel and gas turbine engines, chemical catalysis, coal gasification, biomolecular dynamics and function, and fast nuclear reactor core flow and fuel performance. Table 7 illustrates a few of these accomplishments.

Testimonies from scientists on these teams illustrate the role of leadership computing and LCF staff in helping to deliver these accomplishments:

- "This allows us to look at the waves in ITER. We need much more resolution with ITER because it's so big and the wavelength is so small." (Fred Jaeger, ORNL)

- "If low-temperature compression ignition systems employing lean, dilute fuel mixtures make their way into next-generation autos, fuel efficiency could increase by as much as 25 to 50 percent." (Jacqueline Chen, Sandia National Laboratories)

- "[Our LCF liaison] has been a crucial person in this effort, especially for code optimization." (Jeff Candy, General Atomics)

- 'NCCS [ORNL's National Center for Computational Sciences] has enabled the vital 
breakthrough. The allocation has helped investigating the multiple enzymes from multiple species in a short duration." (Pratul Agarwal, ORNL)

Table 7. Recent energy assurance accomplishments enabled by leadership computing

\begin{tabular}{|c|c|c|c|}
\hline Accomplishment & Description & Impact & Leadership computing role \\
\hline $\begin{array}{l}\text { ITER plasma } \\
\text { core turbulence } \\
\text { characterization }\end{array}$ & $\begin{array}{l}\text { Validation of fusion } \\
\text { plasma microturbulence }\end{array}$ & $\begin{array}{l}\text { Identify and understand core } \\
\text { plasma turbulence modes to be } \\
\text { controlled in the ITER fusion } \\
\text { reactor }\end{array}$ & $\begin{array}{l}\text { More validation studies and } \\
\text { increased physics fidelity }\end{array}$ \\
\hline $\begin{array}{l}\text { Wave-plasma } \\
\text { interaction and } \\
\text { extended } \\
\text { magneto- } \\
\text { hydrodynamics in } \\
\text { fusion systems }\end{array}$ & $\begin{array}{l}\text { Understanding of the } \\
\text { radiofrequency (RF) } \\
\text { heating mechanisms and } \\
\text { the interaction of RF with } \\
\text { magnetohydrodynamics } \\
\text { (MHD) and other plasma } \\
\text { processes in the ITER } \\
\text { fusion reactor }\end{array}$ & $\begin{array}{l}\text { Use at least } 40 \text { megawatts of } \\
\text { RF power to heat the plasma in } \\
\text { the } \$ 13 \text { billion ITER reactor, } \\
\text { making it ten times hotter than } \\
\text { the center of the sun }\end{array}$ & $\begin{array}{l}\text { Higher fidelity and more } \\
\text { predictive RF simulation } \\
\text { more than triple the } \\
\text { resolution of earlier } \\
\text { simulations; coupled models } \\
\text { of RF with MHD }\end{array}$ \\
\hline $\begin{array}{l}\text { Turbulent } \\
\text { combustion } \\
\text { characterization }\end{array}$ & $\begin{array}{l}\text { Stabilization studies of } \\
\text { lifted turbulent } \mathrm{H}_{2} / \text { air jet } \\
\text { flames in ignitive coflow }\end{array}$ & $\begin{array}{l}\text { Develop fundamental } \\
\text { understanding of "turbulence } \\
\text { chemistry" interactions in } \\
\text { combustion: flame stabilization } \\
\text { in an ignitive environment } \\
\text { relevant to diesel engines and } \\
\text { gas turbines }\end{array}$ & $\begin{array}{l}\text { Enabling of combined } \\
\text { Reynolds number and } \\
\text { chemical complexity } \\
\text { consistent with laboratory- } \\
\text { scale flames and autoignition } \\
\text { experiments }\end{array}$ \\
\hline $\begin{array}{l}\text { Coal gasification } \\
\text { pilot plant studies }\end{array}$ & $\begin{array}{l}\text { Development and } \\
\text { application of a gasifier } \\
\text { model to help design } \\
\text { gasifier systems for DOE's } \\
\text { FutureGen project }\end{array}$ & $\begin{array}{l}\text { Design advanced, } \\
\text { zero-emission fossil fuel plant }\end{array}$ & $\begin{array}{l}\text { Performance scaling and } \\
\text { optimization of multiphase } \\
\text { flow model through new } \\
\text { parallel algorithm insertion }\end{array}$ \\
\hline $\begin{array}{l}\text { Rational design } \\
\text { of chemical } \\
\text { catalysts }\end{array}$ & $\begin{array}{l}\text { Dynamics of alkalis on } \\
\text { catalytic metal surfaces } \\
\text { and their promotion in } \\
\text { Fischer-Tropsch processes }\end{array}$ & $\begin{array}{l}\text { More efficiently produce } \\
\text { synthetic petroleum substitute } \\
\text { from coal or natural gas }\end{array}$ & $\begin{array}{l}\text { Fast turnaround time for } \\
\text { rigorous parametric studies }\end{array}$ \\
\hline $\begin{array}{l}\text { Biomolecular } \\
\text { structure, } \\
\text { dynamics, and } \\
\text { function }\end{array}$ & $\begin{array}{l}\text { Evolutionary conservation } \\
\text { of protein structure based } \\
\text { on reaction promoting } \\
\text { vibrations }\end{array}$ & $\begin{array}{l}\text { Enable low-cost bioethanol } \\
\text { production }\end{array}$ & $\begin{array}{l}\text { Fast turnaround time for } \\
\text { reaction path simulations; } \\
\text { reactive systems simulation } \\
\text { instead of selective states }\end{array}$ \\
\hline
\end{tabular}

LCF staff members were indispensable to these achievements; their contributions included the importing of a new sparse linear solver, implementation of asynchronous input/output and automated end-to-end workflows, and achievement of more than $70 \%$ of peak performance in the computeintensive portion of a fusion plasma application. Figure 7 is a direct numerical simulation of turbulent combustion recently performed on the Jaguar LCF system, namely the first fully-resolved simulation of a three-dimensional lifted flame in heated coflow with detailed chemistry. 


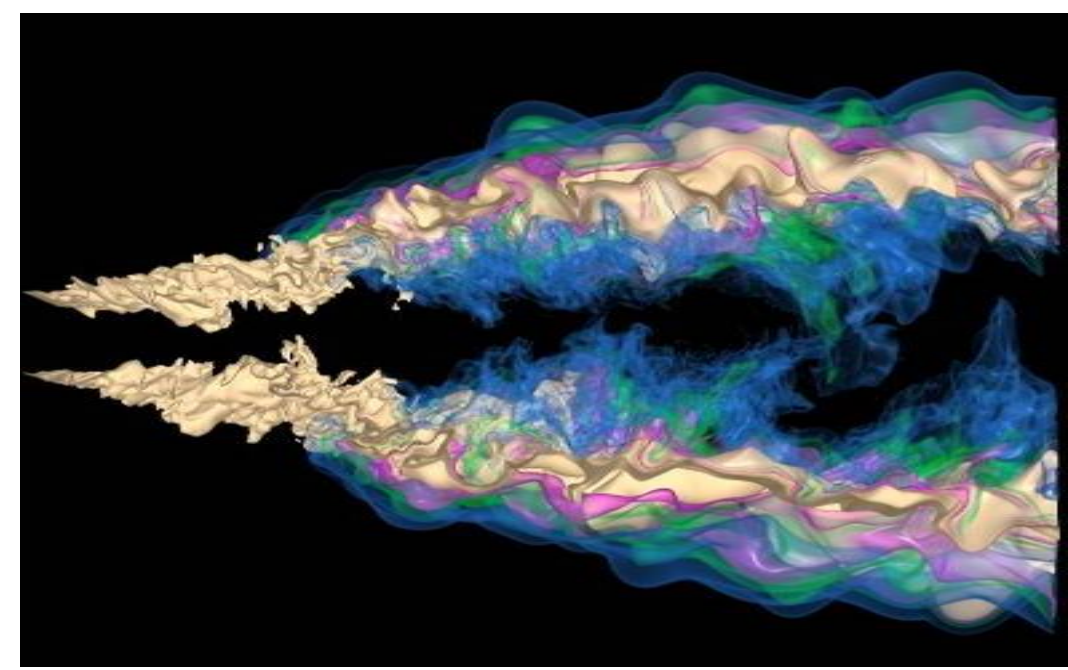

Fig. 7. Direct numerical simulation of flame stabilization in a lifted hydrogen flame. Image shows the mixture fraction iso-surface ( $\tan )$ and volume rendering of the $\mathrm{OH}$ radical concentration. [18]

\subsection{NEAR-TERM (PETASCALE) SCIENCE DRIVERS}

Petascale leadership systems, only a few years down the road, give us increased hope for tackling the nation's energy assurance challenges, as illustrated by the science objectives and impacts presented in Table 8. The following are among these possibilities:

- understanding how some microbial enzymes in nature (cellulase, etc.) break down cellulose into sugars;

- coupling wall, edge, and core physics into one integrated ITER simulation tool;

- deciphering the subtle coupling between turbulent transport and chemical kinetics controlling the stabilization of lifted fuel jets in lean, low-temperature combustion;

- exploiting insight provided by the first coupled, geometrically faithful, and physics-inclusive simulations of an entire nuclear reactor core; and

- understanding physicochemical design coprocesses - from atomic to continuum to geological time and length scales - involved in the reprocessing of spent nuclear fuel for producing recycled fuel and safe, stable waste forms.

In short, petascale leadership computing platforms will help to move energy assurance research from simplified, single-physics studies to more realistic systems that include the relevant phenomena. It will be an important next step toward predictability.

Figure 8 provides just one example of the types of bioenergy simulations that can be performed today.

\subsection{LONGER-TERM (SUSTAINED PETASCALE AND EXASCALE) SCIENCE DRIVERS}

Energy assurance drivers for exascale computing, as shown in Table 9, bring even more promise for new and innovative solutions to the nation's energy challenges. Highlights include the following:

- breaking down the natural resistance of plant cell walls by microbial and enzymatic deconstruction, collectively known as biomass recalcitrance [19], to enable economically viable biofuels; 
Table 8. Select energy assurance drivers for leadership computing at the petascale (1 to 3 years)

\begin{tabular}{|c|c|c|c|}
\hline Application area & Science driver & Science objective & Impact \\
\hline Bioenergy & $\begin{array}{l}\text { Exploration of the } \\
\text { multiscale structure, } \\
\text { dynamics, and function } \\
\text { of enzyme complexes }\end{array}$ & $\begin{array}{l}\text { Evolve multimillion-atom } \\
\text { systems over } 0.1 \text { to } 1.0 \\
\text { millisecond for multiple ( } 200 \text { to } \\
2,000) \text { trajectories }\end{array}$ & $\begin{array}{l}\text { Identification of efficient means } \\
\text { of converting biomass } \\
\text { (cellulose) to ethanol }\end{array}$ \\
\hline \multirow[t]{2}{*}{ Fusion } & $\begin{array}{l}\text { Development of a } \\
\text { quantitative, predictive } \\
\text { tool for wave heating of } \\
\text { ITER plasmas }\end{array}$ & $\begin{array}{l}\text { Complete simulation of mode } \\
\text { conversion heating in ITER } \\
\text { with a realistic antenna } \\
\text { geometry and non-Maxwellian } \\
\text { alpha particles }\end{array}$ & $\begin{array}{l}\text { Design and operation of ITER } \\
\text { RF antenna }\end{array}$ \\
\hline & $\begin{array}{l}\text { Understanding and } \\
\text { quantification of physics } \\
\text { and properties of ITER } \\
\text { scaling and H-mode } \\
\text { confinement }\end{array}$ & $\begin{array}{l}\text { Conduct strongly coupled and } \\
\text { consistent wall-to-edge-to-core } \\
\text { modeling of ITER plasmas; } \\
\text { attain a realistic assessment of } \\
\text { ignition margins }\end{array}$ & Design and operation of ITER \\
\hline \multirow[t]{2}{*}{ Chemistry } & Computational catalysis & $\begin{array}{l}\text { Accurately describe large } \\
\text { systems with modern hybrid and } \\
\text { meta density functional theory } \\
\text { functionals }\end{array}$ & $\begin{array}{l}\text { Generation of quantitative } \\
\text { catalytic reaction rates and } \\
\text { guidance of small-system } \\
\text { calibration }\end{array}$ \\
\hline & $\begin{array}{l}\text { Heavy-element } \\
\text { chemistry for advanced } \\
\text { fuel cycles and } \\
\text { environmental } \\
\text { restoration }\end{array}$ & $\begin{array}{l}\text { Simulate select liquid-liquid } \\
\text { and gas-gas interfaces with } \\
\text { accurate thermochemistry and } \\
\text { spectroscopy }\end{array}$ & $\begin{array}{l}\text { Replacement of many } \\
\text { expensive experiments and } \\
\text { shortening of timescales from } \\
\text { decades to years for } \\
\text { implementation of new nuclear } \\
\text { fuel reprocessing }\end{array}$ \\
\hline Combustion & $\begin{array}{l}\text { Development of a } \\
\text { predictive engineering } \\
\text { simulation tool for new } \\
\text { engine design }\end{array}$ & $\begin{array}{l}\text { Understand flame stabilization } \\
\text { in lifted autoigniting diesel fuel } \\
\text { jets relevant to low-temperature } \\
\text { combustion for engine design at } \\
\text { realistic operating conditions }\end{array}$ & $\begin{array}{l}\text { Potential for 50-percent } \\
\text { increase in efficiency and 20- } \\
\text { percent savings in petroleum } \\
\text { consumption with lower- } \\
\text { emissions, leaner-burning } \\
\text { engines }\end{array}$ \\
\hline \multirow[t]{3}{*}{ Nuclear energy } & $\begin{array}{l}\text { Design, safety analysis, } \\
\text { and licensing support of } \\
\text { fast reactor core physics }\end{array}$ & $\begin{array}{l}\text { Create coupled model of core } \\
\text { thermal hydraulics, structural } \\
\text { mechanics, neutronics, and fuel } \\
\text { performance with acceptable } \\
\text { resolution for geometry and } \\
\text { neutron energy and direction }\end{array}$ & $\begin{array}{l}\text { Reduction of reactor concept- } \\
\text { to-license cycle time and cost; } \\
\text { reduction of operating margins } \\
\text { while maintaining adequate } \\
\text { safety margins }\end{array}$ \\
\hline & $\begin{array}{l}\text { Converged reactor } \\
\text { neutron flux and } \\
\text { spectrum distribution }\end{array}$ & $\begin{array}{l}\text { Analyze } 10^{12} \text { spatial elements } \\
\text { and } 30,000 \text { discrete energy } \\
\text { points; one calculation per } \\
\text { temperature-feedback iteration } \\
\text { per quasi-static time step for a } \\
\text { total of } 10^{21} \text { unknowns } \\
\text { performed } 1,000 \text { times }\end{array}$ & $\begin{array}{l}\text { Accurate reactor core energy } \\
\text { distribution and output for a } \\
\text { given fuel type and age }\end{array}$ \\
\hline & $\begin{array}{l}\text { Design, safety analysis, } \\
\text { and licensing support of } \\
\text { separations reprocessing } \\
\text { plants }\end{array}$ & $\begin{array}{l}\text { Perform coupled, multiscale } \\
\text { simulation of all major unit } \\
\text { operations in a separations plant } \\
\text { with acceptable resolution of } \\
\text { chemical species in all streams }\end{array}$ & $\begin{array}{l}\text { Reduction of plant concept-to- } \\
\text { license cycle time and cost; } \\
\text { production of economic } \\
\text { products for fuel fabrication and } \\
\text { stable waste forms for safe } \\
\text { disposition }\end{array}$ \\
\hline
\end{tabular}




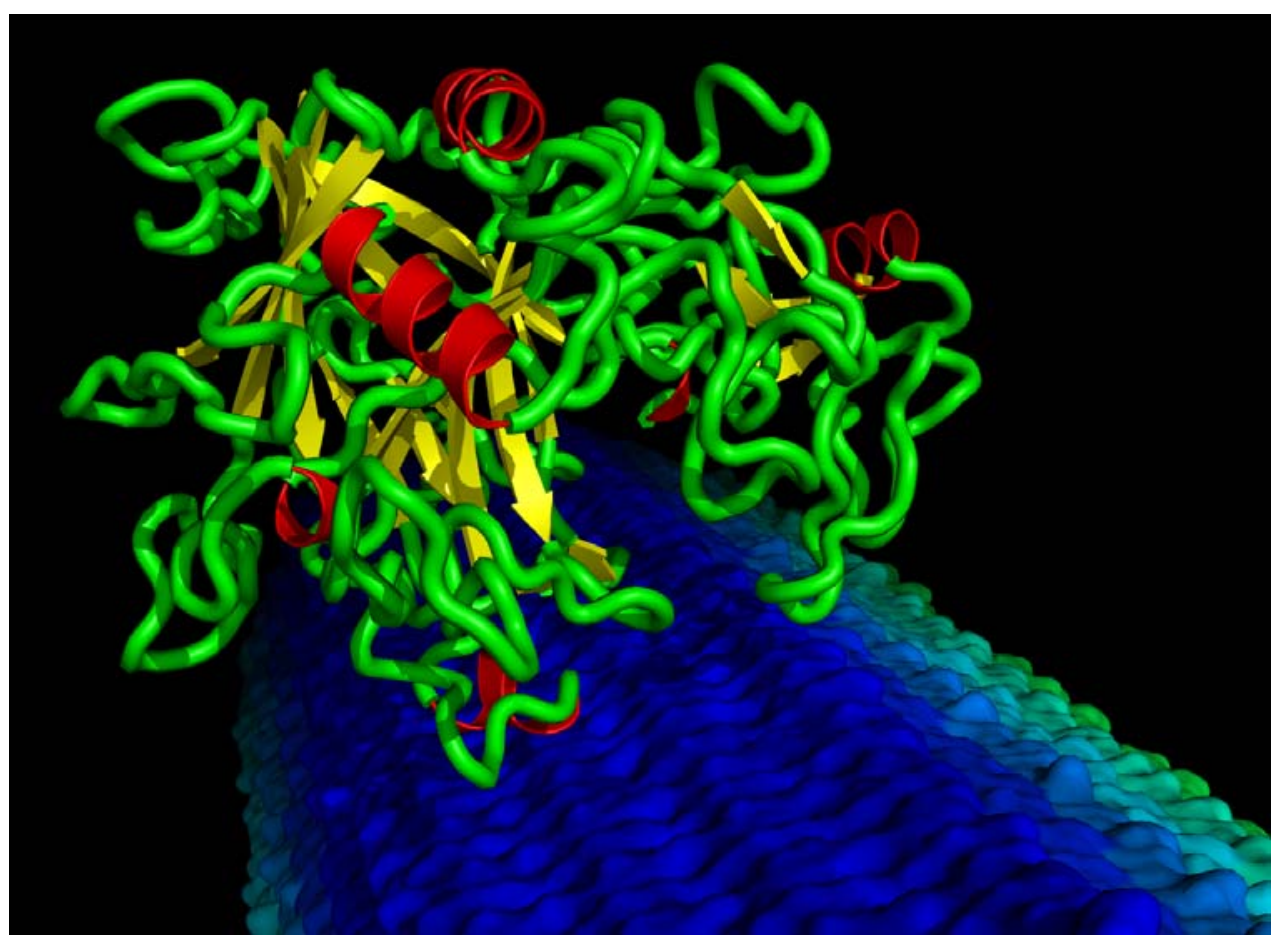

Fig. 8. Recent simulation of a cellulase enzyme attacking a cellulose substrate performed at the LCF [20].

Table 9. Select energy assurance drivers for leadership computing at the exascale (10 years)

\begin{tabular}{llll}
\hline Application area & \multicolumn{1}{c}{ Science driver } & \multicolumn{1}{c}{ Science objective } & \multicolumn{1}{c}{ Impact } \\
\hline Bioenergy & Biomass recalcitrance & $\begin{array}{l}\text { Understand the complexity of } \\
\text { plant cell wall structure and its } \\
\text { relationship to recalcitrance } \\
\text { through large-scale (microbial } \\
\text { and plant cell wall structure and } \\
\text { cellulosome, etc.) simulations of }\end{array}$ & $\begin{array}{l}\text { The most important current } \\
\text { barrier to the emergence of } \\
\text { cellulosic biofuels industry }\end{array}$ \\
& & $\begin{array}{l}10 \text { to } 100 \text { million atoms over } \\
\text { millisecond timeframes }\end{array}$ & \\
Nuclear energy & $\begin{array}{l}\text { Develop an integrated set of } \\
\text { models and simulations of the }\end{array}$ & $\begin{array}{l}\text { A decision-making tool to } \\
\text { help predict the outcome of } \\
\text { changes made to the syste } \\
\text { cimulator for facilities } \\
\text { within an operating } \\
\text { closed fuel cycle }\end{array}$ \\
& $\begin{array}{l}\text { complete set of physical } \\
\text { processes and facilities within } \\
\text { an operating fuel cycle }\end{array}$ & $\begin{array}{l}\text { as it operates } \\
\text { Aqueous fuel } \\
\text { reprocessing }\end{array}$ \\
& $\begin{array}{l}\text { Perform a first-principles } \\
\text { simulation of interfacial } \\
\text { transport in solvent extraction } \\
\text { cycles for aqueous-based } \\
\text { reprocessing }\end{array}$ & $\begin{array}{l}\text { Design novel flowsheets } \\
\text { with reliable scale-up to } \\
\text { commercial reprocessing } \\
\text { plants }\end{array}$ \\
& & &
\end{tabular}


Table 9. (continued)

\begin{tabular}{|c|c|c|c|}
\hline Application area & Science driver & Science objective & Impact \\
\hline \multirow[t]{2}{*}{ Fusion } & $\begin{array}{l}\text { Reliable, whole-device } \\
\text { modeling of ITER }\end{array}$ & $\begin{array}{l}\text { Couple auxiliary heating, MHD } \\
\text { dynamics, and plasma core and } \\
\text { edge codes }\end{array}$ & $\begin{array}{l}\text { Design and operation of } \\
\text { ITER }\end{array}$ \\
\hline & $\begin{array}{l}\text { Predictive and self- } \\
\text { consistent simulation of } \\
\text { ITER plasma profile } \\
\text { evolution }\end{array}$ & $\begin{array}{l}\text { Understand anomalous transport } \\
\text { at the plasma edge and MHD } \\
\text { coupling to turbulence }\end{array}$ & $\begin{array}{l}\text { Design and operation of } \\
\text { ITER }\end{array}$ \\
\hline Combustion & $\begin{array}{l}\text { Understanding of } \\
\text { "flameless" combustion } \\
\text { of diverse fuels at high } \\
\text { pressure in a turbulent } \\
\text { environment relevant to } \\
\text { advanced fuel-efficient, } \\
\text { low-emissions engine } \\
\text { concepts }\end{array}$ & $\begin{array}{l}\text { Perform direct simulation of } \\
\text { nonconventional, mixed-mode, } \\
\text { turbulent combustion of biofuels } \\
\text { under compression-ignition, } \\
\text { aero-thermo-chemical regimes } \\
\text { accounting for emission using } \\
\text { statistical moments and models } \\
\text { for particulate matter }\end{array}$ & $\begin{array}{l}\text { New combustion systems } \\
\text { designed to use alternative } \\
\text { fuels with high efficiency } \\
\text { while meeting stringent } \\
\text { requirements on emissions }\end{array}$ \\
\hline National security & $\begin{array}{l}\text { Urban modeling for } \\
\text { homeland security }\end{array}$ & $\begin{array}{l}\text { Enable highly accurate three- } \\
\text { dimensional radiation transport } \\
\text { with up to } \sim 1 \text { million unknowns } \\
\text { per grid cell using high numbers } \\
\text { of moments, energy groups, and } \\
\text { angles per cell }\end{array}$ & $\begin{array}{l}\text { Threat analysis and } \\
\text { prediction of improvised } \\
\text { nuclear explosive effects }\end{array}$ \\
\hline Chemistry & $\begin{array}{l}\text { Systematic, large-scale } \\
\text { exploration of optimal } \\
\text { materials for catalysis or } \\
\text { nuclear material } \\
\text { separation agents }\end{array}$ & $\begin{array}{l}\text { Combine density functional } \\
\text { theory with evolutionary search } \\
\text { for complex materials or an } \\
\text { accurate combinatorial approach } \\
\text { to screen the best separation } \\
\text { material out of } \mathrm{O}\left(10^{3}\right) \\
\text { compounds }\end{array}$ & $\begin{array}{l}\text { Virtual design of catalysts } \\
\text { and separating agents }\end{array}$ \\
\hline
\end{tabular}

- building and using a "virtual simulator" for advanced nuclear fuel cycles to guide the design and construction of new major nuclear facilities (thermal and recycling reactors, reprocessing facilities, and waste form treatment);

- demonstrating the scientific and technical feasibility of fusion power with the successful design and operation of the ITER facility [21];

- guiding and optimizing biofuels-consuming combustion engine design and operation by understanding fuel effects on fundamental combustion processes; and

- selecting and designing chemical catalysts quickly, cheaply, and efficiently via "virtual selection," or with a minimum of experiments.

The bioenergy driver in Table 8 is just one example of the opportunities and insights afforded by exascale systems. The need to routinely model biomolecular complexes on their natural timescale, namely milliseconds (see Fig. 9), is currently impossible because today's molecular dynamics simulation tools possess algorithms that must integrate forward in time with extremely small $\left(10^{-12}\right.$ second) time steps to maintain the requisite accuracy and stability. Exascale systems will put this requirement in the past, for the first time allowing the kinds of turnkey simulations of enzyme function and protein dynamics needed for real progress in understanding structure and function. 


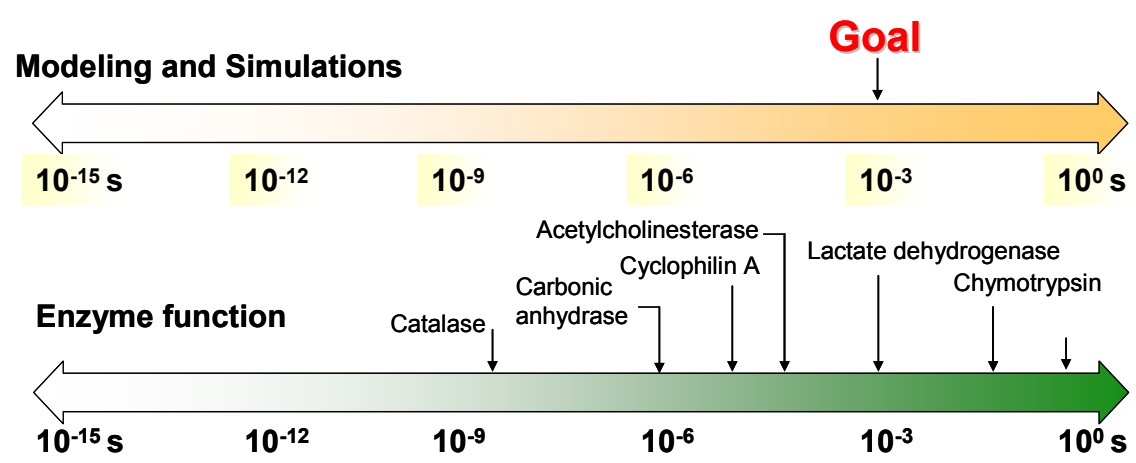

\section{Protein dynamical events}

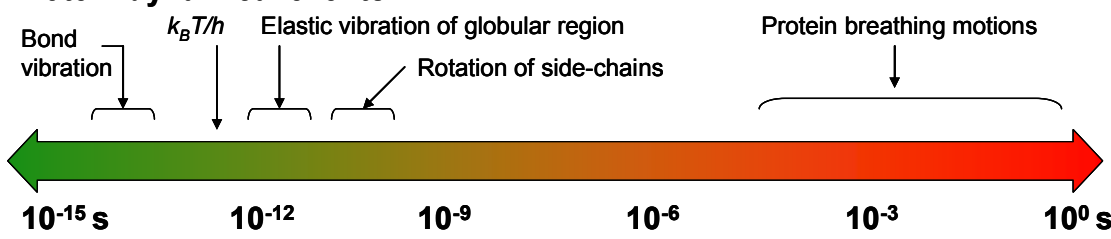

Fig. 9. Many protein and enzyme events of interest to biology and bioenergy research are in the millisecond-to-second timescales [22, 23], which are orders of magnitude beyond those possible with today's simulations. Exascale leadership systems will change this landscape, making these simulations routine.

Recognition of the ITER facility's dependence on petascale and exascale computing has led to the recently chartered Fusion Simulation Project (FSP), whose primary objective is to "create highperformance software to carry out comprehensive predictive integrated modeling simulations, with high physics fidelity, relevant to ITER" [24]. ITER is DOE's highest-priority scientific facility [25]. The commitment to ITER and the urgent need for the FSP represent major energy assurance drivers for exascale computing. The FSP charter calls for development and application of a fully verified and validated comprehensive modeling capability to meet the following requirements [24]:

- Because each ITER discharge will be very costly (more than $\$ 1$ million), predictive, wholedevice simulation is needed to optimize discharge scenarios.

- Simulation-guided controls must be developed to suppress large-scale instabilities adversely affecting confinement prior to completion of ITER construction.

- Accurate and reliable predictions are needed for edge transport barrier (enhancing core plasma confinement) and edge instabilities (causing fluctuations in divertor and first wall power).

ITER is dependent upon exascale computing for both optimal design (prior to 2017) and operational success (beyond 2017). This is true not only for the reasons cited above, but also because ITER is far larger than current experimental fusion reactors, with a toroidal magnetic field, minor radius, and electron temperature one to two orders of magnitude greater than those of current operational devices (CDX-U, DIII-D, etc.). As a result, a whole-device simulation of ITER will require $10^{12}$ more space-time points than current simulations of experimental devices. These 12 orders of magnitude cannot be achieved without both key software (algorithm) advancements and exascale computing [24].

U.S. energy assurance cannot be realized without science, technology, and innovation. A successful strategy will require prolific science and technology activity targeting all energy sectors to drive innovation and technology-based solutions. Such a strategy must use exascale leadership computing to meet an aggressive schedule — two decades — for achieving U.S. energy assurance. 


\section{FUNDAMENTAL SCIENCE}

\subsection{RECENT ACCOMPLISHMENTS WITH LEADERSHIP COMPUTING}

Fundamental science — defined here as fields such as high-energy physics, accelerator physics, nuclear physics, and astrophysics - has traditionally relied heavily on computer and computational science as an enabling tool for discoveries, breakthroughs, and new insight. Leadership computing has arguably been an even more vital tool because the breadth of fundamental science exploration often increases with the size - in memory and speed - of the computational resource employed. A few recent accomplishments in fundamental science are illustrated in Table 10, with noteworthy advances that include the following:

- Astrophysics simulations at the LCF have decisively changed the standard model of core-collapse supernova evolution and explosion (Fig. 10). The (wholly computational) discovery of the standing accretion shock instability (SASI) is a fundamentally new piece of supernova theory, and the SASI has become the framing concept for most current supernova simulations. The first generation of multidimensional radiation-hydrodynamic simulations of core-collapse supernovas with sophisticated spectral neutrino transport and detailed nuclear burning are beginning to incorporate the effects of the SASI.

- The first-ever nuclear physics coupled-cluster simulations of ${ }^{40} \mathrm{Ca}$ have led to the determination of its ground state properties, including realistic three-body interactions.

Table 10. Recent fundamental science accomplishments enabled by leadership computing

\begin{tabular}{|c|c|c|c|}
\hline Accomplishment & Description & Impact & Leadership computing role \\
\hline $\begin{array}{l}\text { Astrophysics } \\
\text { core-collapse } \\
\text { supernova pulsar } \\
\text { mechanism } \\
\text { explanation }\end{array}$ & $\begin{array}{l}\text { Discovery of fundamental } \\
\text { instability of supernova } \\
\text { shocks through simulation }\end{array}$ & $\begin{array}{l}\text { Determine that the SASI } \\
\text { not only directly impacts } \\
\text { the explosion mechanism } \\
\text { in core-collapse } \\
\text { supernovas, but also } \\
\text { provides an explanation } \\
\text { for pulsar spin-up }\end{array}$ & $\begin{array}{l}\text { Ability to explore long (greater } \\
\text { than half a second) physical } \\
\text { timescales, essential to the } \\
\text { discovery of the SASI }\end{array}$ \\
\hline $\begin{array}{l}\text { Nuclear physics } \\
\text { ground state } \\
\text { determination of } \\
{ }^{40} \mathrm{Ca}\end{array}$ & $\begin{array}{l}\text { First-ever }{ }^{40} \mathrm{Ca} \text { calculation } \\
\text { using modern } \\
\text { coupled-cluster theory and } \\
\text { interactions, including } \\
\text { triples correlations }\end{array}$ & $\begin{array}{l}\text { Support nuclear structure } \\
\text { research with exotic beams } \\
\text { and enable reliable } \\
\text { predictions of unknown } \\
\text { nuclei crucial for } \\
\text { astrophysical modeling }\end{array}$ & $\begin{array}{l}\text { Required computation with } \\
\text { several thousand processors }\end{array}$ \\
\hline $\begin{array}{l}\text { Astrophysics } \\
\text { core-collapse } \\
\text { supernova } \\
\text { explosion } \\
\text { mechanism } \\
\text { explanation }\end{array}$ & $\begin{array}{l}\text { Simulations of core- } \\
\text { collapse supernovas with } \\
\text { realistic neutrino transport } \\
\text { and nuclear burning } \\
\text { coupled to } \\
\text { multidimensional } \\
\text { hydrodynamics leading to } \\
\text { explosions }\end{array}$ & $\begin{array}{l}\text { Solve core-collapse } \\
\text { supernova explosion- } \\
\text { mechanism puzzle after } \\
\text { more than } 40 \text { years }\end{array}$ & $\begin{array}{l}\text { Ability to model neutrino } \\
\text { transport, nuclear burning, and } \\
\text { multidimensional } \\
\text { hydrodynamics }\end{array}$ \\
\hline
\end{tabular}




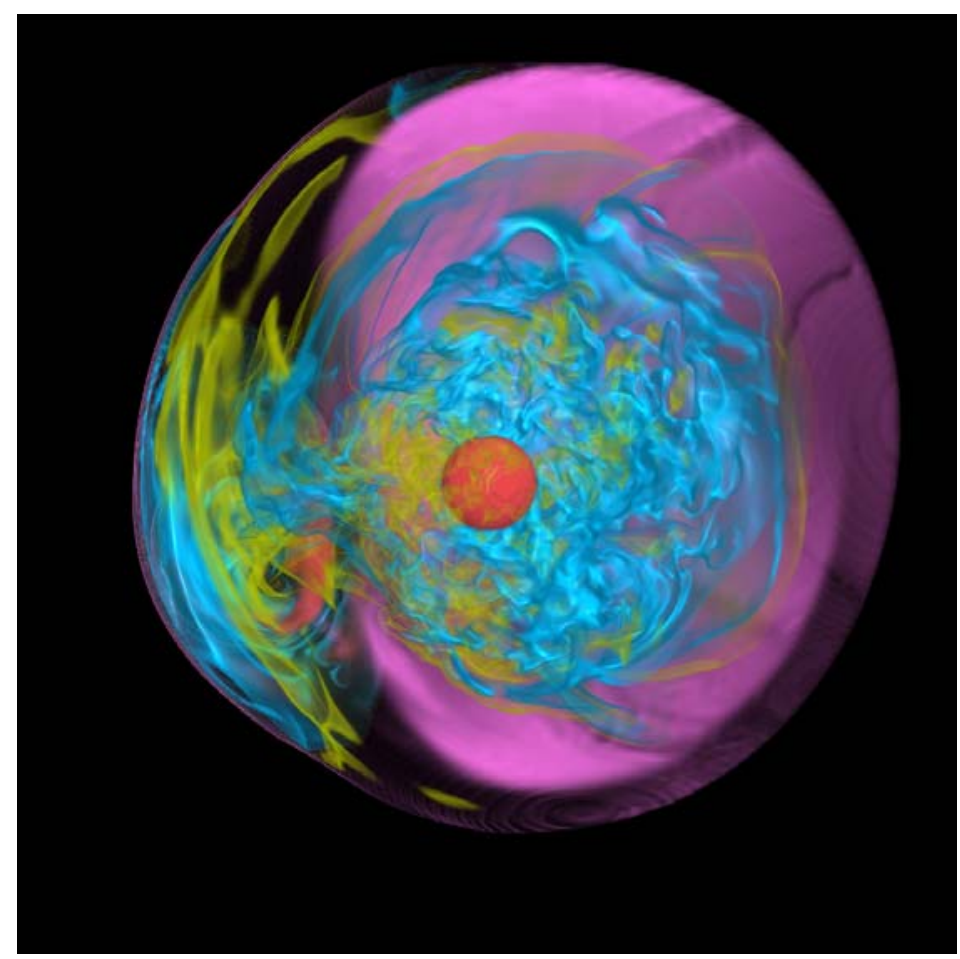

Fig. 10. Rendering of the matter entropy during the nonlinear phase of the standing accretion shock instability in a supernova core [26].

Testimonies from scientists on these teams illustrate the role of leadership computing and LCF staff in helping to deliver these accomplishments:

- "We cannot do the medium-mass nuclei in coupled-cluster theory without the resources. The same holds for diagonalization techniques; mass tables from DFT [density functional theory] all require both turnaround and large runs." (David Dean, ORNL)

- "With the machine being more stable and larger, it has been easier to perform production science runs. [The LCF liaison] has been instrumental in our progress this quarter. This is the very best aspect of the NCCS-LCF structure and relationship." (Anthony Mezzacappa, ORNL)

\subsection{NEAR-TERM (PETASCALE) SCIENCE DRIVERS}

It is no surprise that the fundamental science community is prepared to take advantage of petascale computing with an abundance of fundamental science drivers and very specific objectives. This community, like the climate community, is very articulate and quantitative about its science needs and objectives and about what it expects to gain from petascale computing. In astrophysics, for example, petascale-level core-collapse supernova simulations will attempt to definitively determine the explosion mechanism and make quantitative statements regarding many of the most important observables (nucleosynthesis, gravitational waves, neutrino signatures, etc.). This is an exciting statement indeed, as the explosive mechanism has been both elusive and controversial for decades. This and other select fundamental science challenges at the petascale are highlighted in Table 11. 
Table 11. Select fundamental science drivers for leadership computing at the petascale (1 to 3 years)

\begin{tabular}{|c|c|c|c|}
\hline Application area & Science driver & Science objective & Impact \\
\hline \multirow[t]{2}{*}{ Astrophysics } & $\begin{array}{l}\text { Understanding of the } \\
\text { core-collapse supernova } \\
\text { mechanism for a range } \\
\text { of progenitor star } \\
\text { masses }\end{array}$ & $\begin{array}{l}\text { Perform core-collapse } \\
\text { simulations with sophisticated } \\
\text { spectral neutrino transport, } \\
\text { detailed nuclear burning, and } \\
\text { general relativistic gravity }\end{array}$ & $\begin{array}{l}\text { Understanding of the origin } \\
\text { of many elements in the } \\
\text { periodic table and the } \\
\text { creation of neutron stars and } \\
\text { black holes }\end{array}$ \\
\hline & $\begin{array}{l}\text { Meeting of need for } \sim 1- \\
\text { percent accuracy in } \\
\text { ability to make Type Ia } \\
\text { supernova standard } \\
\text { candles }\end{array}$ & $\begin{array}{l}\text { Discriminate among Type Ia } \\
\text { supernova detonation } \\
\text { mechanisms and predict } \\
\text { correlations for observers to use } \\
\text { in supernova calibration }\end{array}$ & $\begin{array}{l}\text { Better understanding of dark } \\
\text { energy properties; guidance } \\
\text { of Joint Dark Energy } \\
\text { Mission instrumentation, } \\
\text { scientific observation } \\
\text { strategy, and data analysis }\end{array}$ \\
\hline $\begin{array}{l}\text { Lattice quantum } \\
\text { chromodynamics }\end{array}$ & $\begin{array}{l}\text { Computation of strong } \\
\text { interactions between } \\
\text { particles so precise that } \\
\text { theoretical uncertainties } \\
\text { no longer limit } \\
\text { understanding of their } \\
\text { interactions }\end{array}$ & $\begin{array}{l}\text { Calculate weak interaction } \\
\text { matrix elements of strongly } \\
\text { interacting particles to the } \\
\text { accuracy needed to make } \\
\text { precise tests of the Standard } \\
\text { Model; determine the properties } \\
\text { of strongly interacting matter at } \\
\text { high temperatures and densities, } \\
\text { such as those that existed } \\
\text { immediately after the Big Bang; } \\
\text { calculate the masses of strongly } \\
\text { interacting particles }\end{array}$ & $\begin{array}{l}\text { Unification of the forces and } \\
\text { particles of nature and } \\
\text { understanding of the cosmos } \\
\text { and destiny of the universe }\end{array}$ \\
\hline Nuclear physics & $\begin{array}{l}\text { Ab initio understanding } \\
\text { of nuclear properties and } \\
\text { nuclear reaction } \\
\text { mechanisms }\end{array}$ & $\begin{array}{l}\text { Compute from first principles } \\
\text { the properties of medium-mass } \\
\text { nuclei (mass } 40 \text { to } 100 \text { ) with } \\
\text { two- and three-body nuclear } \\
\text { forces }\end{array}$ & $\begin{array}{l}\text { Predictive capability for } \\
\text { nuclear properties and } \\
\text { scattering cross sections } \\
\text { relevant to DOE programs }\end{array}$ \\
\hline
\end{tabular}

\subsection{LONGER-TERM (SUSTAINED PETASCALE AND EXASCALE) SCIENCE DRIVERS}

Exascale simulation will usher in an era of precision predictive power for numerical experiments in fundamental science, examples of which are given in Table 12 for astrophysics, biology, and nuclear physics.

The impact of delivering on these objectives at the exascale cannot be overstated and include the following:

- understanding the chemical evolution of the galaxy;

- $\quad$ simulating human interaction with microbes (bacteria, viruses, etc.);

- designing drugs virtually;

- designing the International Linear Collider (ILC) accelerator;

- understanding the evolutionary state of a nucleus as it undergoes fission and fusion reactions;

- reconstructing protein structure and function from raw genomic data; and

- improving understanding of proteomics, protein folding, and docking.

Delivering on these and other fundamental science drivers with exascale leadership computing would, by any measure, represent a quantum leap forward in science advancement and discovery. 
Table 12. Select fundamental science drivers for leadership computing at the exascale (10 years)

\begin{tabular}{|c|c|c|c|}
\hline Application area & Science driver & Science objective & Impact \\
\hline Astrophysics & $\begin{array}{l}\text { Detailed simulations of } \\
\text { core-collapse } \\
\text { supernovas, including } \\
\text { nucleosynthesis, } \\
\text { gravitational waves, and } \\
\text { neutrino signatures }\end{array}$ & $\begin{array}{l}\text { Perform core-collapse } \\
\text { simulations with Bolztmann } \\
\text { neutrino transport and nuclear } \\
\text { kinetics capable of isotopic } \\
\text { evolution for a wide range of } \\
\text { stars }\end{array}$ & $\begin{array}{l}\text { Understanding of the } \\
\text { chemical evolution of the } \\
\text { galaxy and the place of } \\
\text { supernovas }\end{array}$ \\
\hline \multirow[t]{3}{*}{ Biology } & $\begin{array}{l}\text { Protein and ligand } \\
\text { interactions }\end{array}$ & $\begin{array}{l}\text { Predict protein structure and } \\
\text { classification, interacting } \\
\text { protein partners, protein-protein } \\
\text { complexes, and structure- } \\
\text { function changes }\end{array}$ & $\begin{array}{l}\text { Understanding of human } \\
\text { interactions with microbes } \\
\text { (bacteria and viruses) }\end{array}$ \\
\hline & $\begin{array}{l}\text { Conformational changes } \\
\text { in the activation of a } \\
\text { voltage-gated potassium } \\
\text { channel that occurs on } \\
\text { the surface of nerve, } \\
\text { muscle, and secretory } \\
\text { cells }\end{array}$ & $\begin{array}{l}\text { Simulate biological systems } \\
\text { (whole organisms such as cells), } \\
\text { including multiple proteins } \\
\text { undergoing assembly and } \\
\text { folding }\end{array}$ & $\begin{array}{l}\text { Regulation of cell- } \\
\text { membrane excitability; } \\
\text { repetitive, low-frequency } \\
\text { firing in some neurons; and } \\
\text { recovery of the nerve-fiber } \\
\text { membrane at the end of the } \\
\text { action potential }\end{array}$ \\
\hline & $\begin{array}{l}\text { Accurate, statistically- } \\
\text { relevant, real-time } \\
\text { biomolecular complex } \\
\text { analysis }\end{array}$ & $\begin{array}{l}\text { Perform classical atomistic } \\
\text { simulations of } 100,000 \text {-atom } \\
\text { systems to } 10 \text {-million-atom } \\
\text { systems with multiple } \\
\text { trajectories in parallel } \\
\text { (ensemble-based approach) and } \\
\text { ab initio quantum- } \\
\text { mechanical/molecular- } \\
\text { mechanical methods for } \\
\text { quantum treatment of biological } \\
\text { systems }\end{array}$ & $\begin{array}{l}\text { Timely and cost-efficient } \\
\text { drug design }\end{array}$ \\
\hline $\begin{array}{l}\text { Accelerator } \\
\text { physics }\end{array}$ & $\begin{array}{l}\text { Optimization and design } \\
\text { of future particle } \\
\text { accelerators for better } \\
\text { efficiency at lower costs } \\
\text { and development of } \\
\text { advanced accelerator } \\
\text { concepts }\end{array}$ & $\begin{array}{l}\text { Include electromagnetic, } \\
\text { thermal and mechanical effects } \\
\text { for the ILC RF unit to determine } \\
\text { optimal linear accelerator design }\end{array}$ & $\begin{array}{l}\text { Increased return on } \\
\text { investment of large DOE } \\
\text { accelerator facilities }\end{array}$ \\
\hline Nuclear physics & $\begin{array}{l}\text { Deciphering of the } \\
\text { evolution in time of } \\
\text { fission and fusion } \\
\text { processes }\end{array}$ & $\begin{array}{l}\text { Use time-dependent coupled- } \\
\text { cluster theory to investigate the } \\
\text { time evolution of "below-the- } \\
\text { barrier" events to deduce } \\
\text { fragment mass and energy } \\
\text { distribution }\end{array}$ & $\begin{array}{l}\text { Reducing uncertainty in } \\
\text { nuclear fusion and fission } \\
\text { reactions }\end{array}$ \\
\hline
\end{tabular}

\section{THE ROAD AHEAD}

While conventional wisdom holds that scientific breakthroughs cannot be planned, we can be confident they will take place. The urgency of our scientific needs, combined with the development of 
exascale computing resources and a driven, talented scientific community, will virtually ensure that the pace of scientific breakthrough continues to accelerate in the coming decade. In fact, with the deployment of increasingly capable leadership systems, the conventional wisdom will give way to a new reality: the planning of scientific discovery, simulation by simulation. Such planning has already been demonstrated for applications in climate, chemistry, combustion, astrophysics, fusion, and communication systems (see Table 13).

Table 13. Science opportunities and impacts grow with increasingly capable leadership systems

\begin{tabular}{|c|c|c|c|}
\hline Application area & Science at 1 petaflop & Science at a sustained petaflop & Science at 1 exaflop \\
\hline Climate & $\begin{array}{l}\text { Mitigation: full } \\
\text { chemistry; cycles of } \\
\text { carbon, nitrogen, and } \\
\text { sulfur; ice-sheet model; } \\
\text { multiple ensembles } \\
\text { Adaptation: high- } \\
\text { resolution (1/4 degree } \\
\text { longitude) atmosphere, } \\
\text { land, sea ice, and ocean }\end{array}$ & $\begin{array}{l}\text { Mitigation: increased resolution, } \\
\text { longer simulations, more } \\
\text { ensembles for reliable } \\
\text { projections; coupling with } \\
\text { socioeconomic and biodiversity } \\
\text { models } \\
\text { Adaptation: limited cloud- } \\
\text { resolving simulations, large- } \\
\text { scale data assimilation }\end{array}$ & $\begin{array}{l}\text { Mitigation: multicentury } \\
\text { ensemble projections for } \\
\text { detailed comparisons of } \\
\text { mitigation strategies } \\
\text { Adaptation: full cloud- } \\
\text { resolving simulations, } \\
\text { decadal forecasts of regional } \\
\text { impacts, and extreme-event } \\
\text { statistics }\end{array}$ \\
\hline Chemistry & $\begin{array}{l}\text { Dynamics of few- } \\
\text { electron systems such as } \\
\text { interaction with intense } \\
\text { radiation }\end{array}$ & $\begin{array}{l}\text { Treatment of absorption } \\
\text { problem with larger unit cells to } \\
\text { avoid error sources }\end{array}$ & $\begin{array}{l}\text { Extension of interaction } \\
\text { with intense radiation to } \\
\text { more realistic systems } \\
\text { containing more electrons }\end{array}$ \\
\hline Combustion & $\begin{array}{l}\text { Stabilization of } \\
\text { autoigniting diesel jets } \\
\text { Predictive models } \\
\text { accounting for turbulent } \\
\text { transport coupling with } \\
\text { multistage ignition and } \\
\text { cool-flame chemistry in } \\
\text { diesel combustion }\end{array}$ & $\begin{array}{l}\text { Liquid jet combustion with } \\
\text { spray dynamics, evaporation, } \\
\text { and chemical reaction at phase } \\
\text { boundaries } \\
\text { Active control of spray shape } \\
\text { and injection parameters for } \\
\text { clean combustion in flexible- } \\
\text { fuel vehicles }\end{array}$ & $\begin{array}{l}\text { Emission in direct injection } \\
\text { combustion using multiple } \\
\text { statistical moments and } \\
\text { stochastic models for } \\
\text { particulate matter } \\
\text { Reduction of soot and } \\
\text { emissions from combustion } \\
\text { of diesel and alternative } \\
\text { fuels such as biobutanol }\end{array}$ \\
\hline Astrophysics & $\begin{array}{l}\text { Determination of the } \\
\text { nature of the core- } \\
\text { collapse supernova } \\
\text { explosion mechanism } \\
\text { Fully integrated, three- } \\
\text { dimensional neutrino } \\
\text { radiation hydrodynamics } \\
\text { simulations with nuclear } \\
\text { burning }\end{array}$ & $\begin{array}{l}\text { Detailed nucleosynthesis } \\
\text { (element production) from core- } \\
\text { collapse supernovas } \\
\text { Large nuclear network capable } \\
\text { of isotopic prediction (along } \\
\text { with energy production) }\end{array}$ & $\begin{array}{l}\text { Precision prediction of } \\
\text { complete observable set } \\
\text { from core-collapse } \\
\text { supernovas: } \\
\text { nucleosynthesis, } \\
\text { gravitational waves, } \\
\text { neutrino signatures, light } \\
\text { output } \\
\text { Full three-dimensional } \\
\text { Boltzmann neutrino } \\
\text { transport, three-dimensional } \\
\text { MHD and relativistic } \\
\text { hydrodynamics, nuclear } \\
\text { burning }\end{array}$ \\
\hline
\end{tabular}


Table 13. (continued)

\begin{tabular}{|c|c|c|c|}
\hline Application area & Science at 1 petaflop & Science at a sustained petaflop & Science at 1 exaflop \\
\hline Fusion & $\begin{array}{l}\text { Study of mesoscale } \\
\text { dynamics, structure } \\
\text { formation, heat and } \\
\text { particle transport in } \\
\text { collisionless trapped } \\
\text { electron mode } \\
\text { turbulence } \\
\text { Comparison of } \\
\text { fluctuation spectra and } \\
\text { zonal flow patterns with } \\
\text { basic energy sciences } \\
\text { data }\end{array}$ & $\begin{array}{l}\text { Initial predictive capability for } \\
\text { the effective coupling of the } \\
\text { plasma core and the plasma } \\
\text { edge region and for MHD } \\
\text { dynamics and auxiliary heating } \\
\text { of the plasma through RF waves }\end{array}$ & $\begin{array}{l}\text { ITER predictive capability: } \\
\text { ion-electron temperature } \\
\text { gradient coupling with } \\
\text { realistic mass ratios and } \\
\text { core-edge coupling } \\
\text { Coupling with edge code } \\
\text { and looking into longer } \\
\text { timescale phenomena }\end{array}$ \\
\hline $\begin{array}{l}\text { Communication } \\
\text { systems (civilian } \\
\text { and defense) }\end{array}$ & $\begin{array}{l}\text { Study of interplay of } \\
\text { weather, signal } \\
\text { propagation, and related } \\
\text { phenomena on system } \\
\text { performance } \\
\text { Study of security and } \\
\text { performance of extant } \\
\text { protocols on Internet- } \\
\text { scale configurations }\end{array}$ & $\begin{array}{l}\text { Increase fidelity of } \\
\text { communications network } \\
\text { physical-layer effects } \\
\text { Incorporation of detailed } \\
\text { communications-network } \\
\text { protocols }\end{array}$ & $\begin{array}{l}\text { Optimization of simulation- } \\
\text { based design process for } \\
\text { robustness and on-demand } \\
\text { tuning for very rapid } \\
\text { deployment }\end{array}$ \\
\hline
\end{tabular}

Planning for scientific discovery will become increasingly important in the coming years, but it must be preceded by planning for the tools of discovery - next-generation computing hardware, algorithms, and applications. We have every reason to assume that the nation's research scientists, armed with these tools, will readily meet the challenges at hand.

\section{REFERENCES}

1. National Center for Computational Sciences. 2007. Computational Science Requirements for Leadership Computing, http://nccs.gov/media-center/nccs-reports, Oak Ridge, Tenn.

2. Department of Energy. 2007. Modeling and Simulation at the Exascale for Energy and the Environment, Office of Science, http://www.mcs.anl.gov/ insley/E3/E3-draft-2007-08-09.pdf, Washington, D.C.

3. Computing Research Associates. 2003. The Roadmap for the Revitalization of High-End Computing, http://www.nitrd.gov/subcommittee/hec/hecrtf-outreach/20040112_cra_hecrtf_ report.pdf.

4. Department of Energy. 2003. A Science-Based Case for Large-Scale Simulation, Office of Science, available at http://www.pnl.gov/scales/.

5. Department of Energy. 2000. Scientific Discovery through Advanced Computing, Office of Science, http://www.scidac.gov/SciDAC.pdf.

6. Department of Energy. 2003. The Challenge and Promise of Scientific Computing, Office of Science, http://www.er.doe.gov/sub/Occasional_Papers/1-Occ-Scientific-Computation.PDF.

7. Oak Ridge National Laboratory. 2004. National Leadership Computing Facility: A Partnership in Computational Sciences, http://www.ccs.ornl.gov/nlcf/. 
8. Butler, W. H., et al., "Spin-dependent tunneling conductance of $\mathrm{Fe}|\mathrm{MgO}| \mathrm{Fe}$ sandwiches," Physical Review B 63, 054416 (2001).

9. Parkin, S.S.P., et al., "Giant tunnelling magnetoresistance at room temperature with $\mathrm{MgO}(100)$ tunnel barriers," Nature Materials 3, 862-867 (2004).

10. Yang, J., and C. Chen. 2007, unpublished work.

11. Drummond, M., et al., "An Electronic Structure Investigation of Surface-Adsorbate and Adsorbate-Adsorbate Interactions in Multilayers of $\mathrm{CH}_{4}$ on $\mathrm{MgO}(100)$," Journal of Physical Chemistry C 111, 966-976 (2007).

12. Schulthess, T., "Solving a Macroscopic Model for High-Temperature Superconductivity," Scientific Computing (2006), http://www.scientificcomputing.com/.

13. Wang, L. W. 2007, unpublished work.

14. Department of Energy. 2006. Petascale Applications Workshop, Office of Science Advanced Scientific Computing Research Program Office Workshop, Washington, D.C.

15. Hack, J., and E. Bierly, Computational and Informational Technology Rate Limiters to the Advancement of Climate Change Science, presentation given to the DOE Advanced Scientific Computing Research Advisory Committee, November 6-7, 2007, http://www.sc.doe.gov/ascr/ ASCAC/presentationpage 1107.html.

16. Kaiper, G. V., U.S. Energy Flow Trends-2002, Lawrence Livermore National Laboratory, June 2004, UCRL-TR-129990-02, https://eed.1lnl.gov/flow/pdf/USEnFlow02-quads.pdf.

17. Weigand, G., Energy Assurance and High Performance Computing, presentation given at the ORNL booth at Supercomputing 2007, November 2007.

18. Yoo, C. S., J. H. Chen, and R. Sankaran, Direct numerical simulation of a turbulent lifted hydrogen/air jet flame in an autoignitive heated coflow, presentation at the 2nd ECCOMAS Thematic Conference on Computational Combustion, 2007.

19. Mann, R., BioEnergy Science Center: A DOE Bioenergy Research Center, presentation at the 2007 Fall Creek Falls Workshop, Nashville, Tennessee, September 2007.

20. Himmel, M., J., et al. unpublished work (2007).

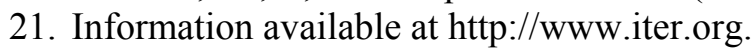

22. Agarwal, P. K., "Enzymes: An integrated view of structure, dynamics and function," Microbial Cell Factories 5:2 (2006), http://www.microbialcellfactories.com/content/5/1/2.

23. Agarwal, P. K., and S. R. Alam, "Biomolecular Simulations on Petascale: Promises and Challenges," Journal of Physics Conference Series 46, 327-333 (2006).

24. Keyes, D., A. Kritz, and W. Tang, Fusion Simulation Project (FSP): Workshop Report, presentation at the DOE Advanced Scientific Computing Research Advisory Committee (ASCAC) meeting, November 2007.

25. Department of Energy. 2007. Four Years Later: An Interim Report on Facilities for the Future of Science: A Twenty-Year Outlook, Office of Science, 2007, http://www.sc.doe.gov/ Scientific_User_Facilities/History/20-Year-Outlook-Interim\%20Report(August).pdf.

26. Blondin, $\overline{\mathrm{J}}$, and A. Mezzacappa, "Pulsar spins from an instability in the accretion shock of supernovae," Nature 445, 58-60 (2007). 